SINAI Journal of Applied Sciences 10 (2) 2021 271-288

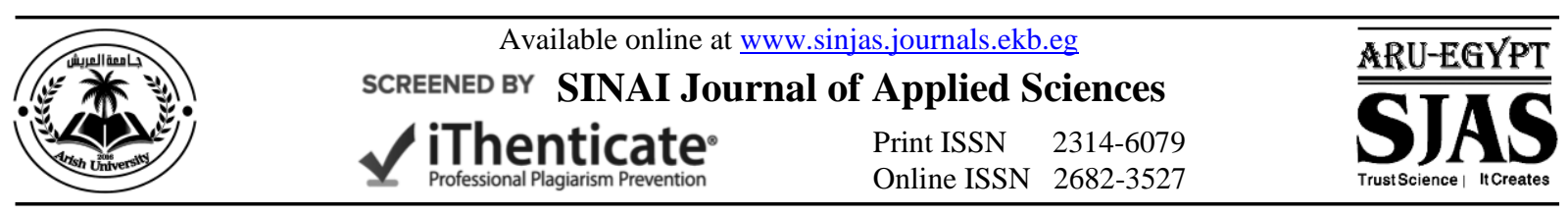

\title{
METHODS OF SOCIAL PROTECTION FOR THE RURAL FAMILY IN ISMAILIA GOVERNORATE
}

\author{
Raed A. Salama ${ }^{1 *}$ and Marwan M. Hassan ${ }^{2}$ \\ 1. Dept. Econ. and Rural Develop., Fac. Environ. Agric. Sci., Arish Univ., Egypt. \\ 2. Dept. Inst. Mang. Fam. and Childhood, Fac. Home Econ., Arish Univ., Egypt.
}

\begin{tabular}{l} 
ARTICLE INFO \\
\hline Article history: \\
Received: $09 / 08 / 2021$ \\
Revised: $31 / 08 / 2021$ \\
Accepted: $19 / 09 / 2021$ \\
Available online: $19 / 09 / 2021$ \\
\hline Keywords: \\
Methods of Social \\
Protection, \\
Social Protection, \\
Rural Family. \\
\\
Check for \\
updates
\end{tabular}

\begin{abstract}
The research aimed to identify the methods of social protection and the degree of utilization from the respondents' point of view. The research was conducted in Ismailia Governorate, and seven villages were selected from the governorate, so that each village represents one of the seven governorate centers. Using both frequencies, percentages, mean, standard deviation, simple correlation coefficient, multiple linear regression, and a reduced model (rising stepwise regression). The research reached many results, the most important of which are the following: The results showed that most of the respondents understand the meaning of the concept of social protection, and the study showed that there are 27 methods of social protection, and the average degree of benefit from them ranges between (1.22-2.63) degrees, The method that benefited the most was the right of rural people to vote and elections, with an average score of 2.63, and the least was the method of rural participation in development projects with an average score of 1.22. The results of the study showed that the ten independent variables studied together explain about $31.1 \%$ of the total variance in the total degree of the respondents' benefit from social protection methods.
\end{abstract}

\footnotetext{
وقد يؤدي الفثل في حماية الفئات المستضعفة إلى الى الى إنى

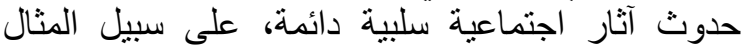

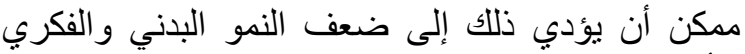

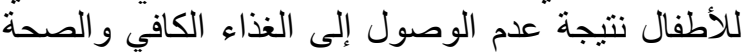

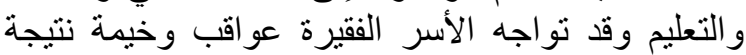

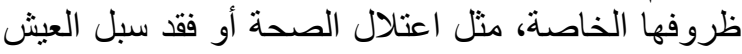

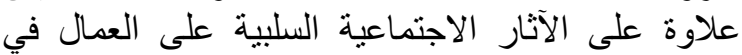
القطاع غير الرسمي (عبدالباقي، 2012).

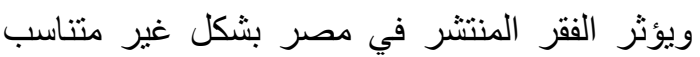

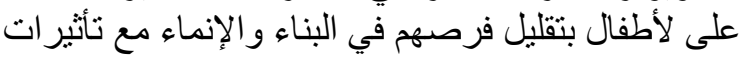

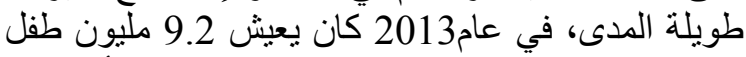

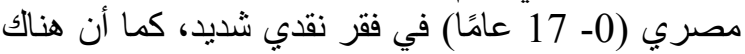

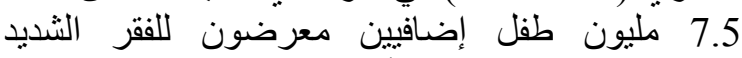
بمعدلات استهلاك بالكاد أعلى من خط الفئ الفقر (الجهاز المركزي للإحصاء، 2015؛ اليونيسف، 2015).

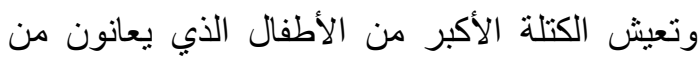

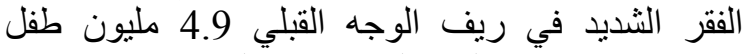

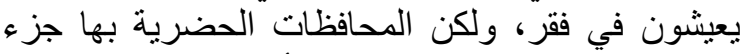
كبير من الزيادة في الفقر خلال الأعوام الماضية (جهاز
}

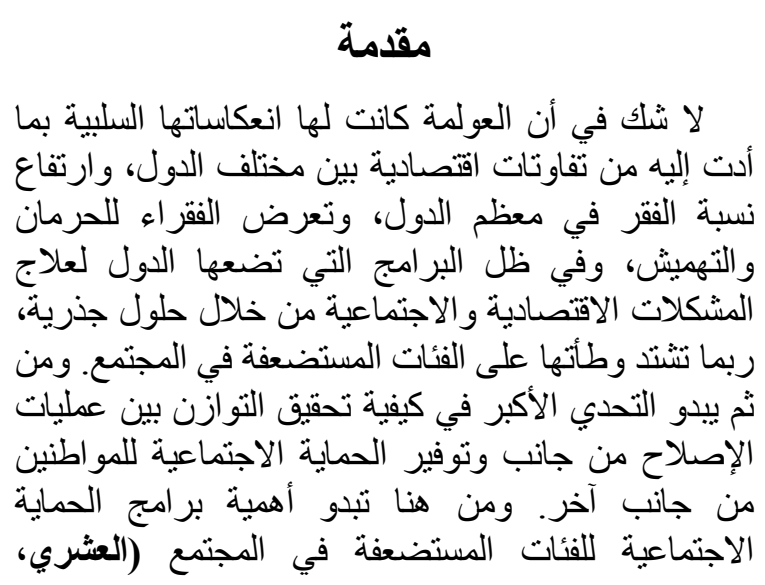

(30:2020

ولهذا تعد الحماية الاجتماعية ركيزة مهمة لتفعيل

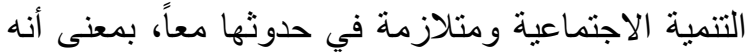

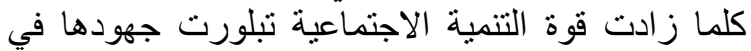

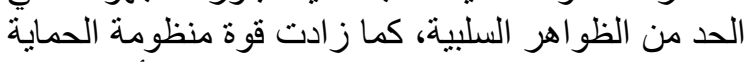

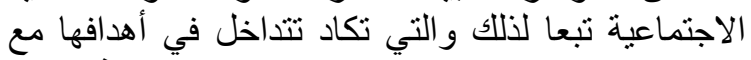

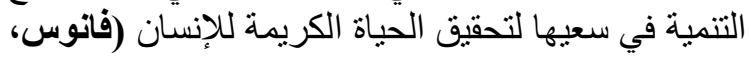

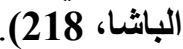

\footnotetext{
* Corresponding author: E-mail address: raed@aru.edu.eg
} https://doi.org/10.21608/sinjas.2021.89939.1039

(C) 2021 SINAI Journal of Applied Sciences. Published by Fac. Environ. Agric. Sci., Arish Univ. All rights reserved. 
3- ما هي درجة استفادة المبحوثين من أساليب الحماية

الاجتماعية التي تقدمها الدولة للأسر الريفية؟

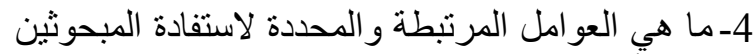

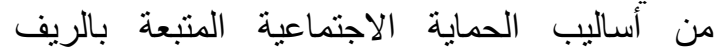

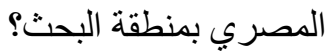

$$
\text { أهـداف البحث }
$$

1- التعرف على مفهوم الحماية الاجتماعية من وجهة نظر المبحوثين بمنطقة البحث.

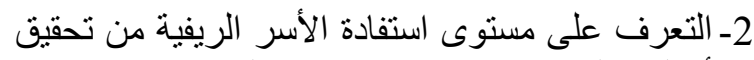
أساليب الحماية الاجتماعية بمنطقة البحث.

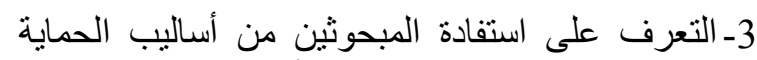
الاجتماعية التي تقدمها الدولة للأسر الريفية من وجهة الكية

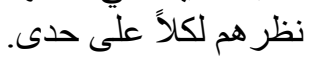

4- التعرف على العوامل المرتبطة والمحددة لاستفادة

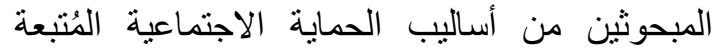
بالريف المصري بمنطقة البحث.

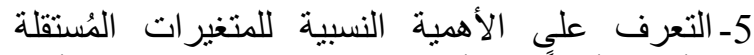

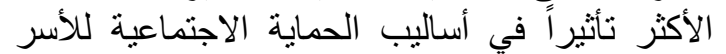

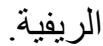

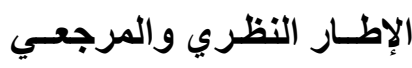

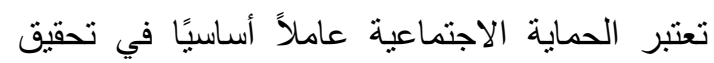

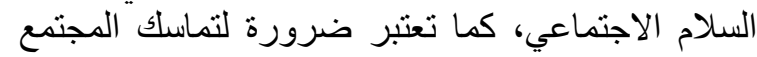

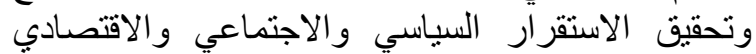
و الأمن القومي (وهبة وآخرون، 2017).

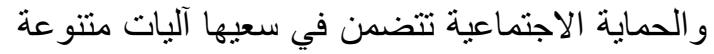

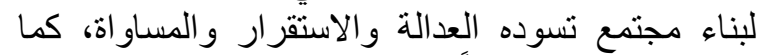
يتضمن سعيها أيضاً تخفيف حدة الأنيف الفقر والتهميش

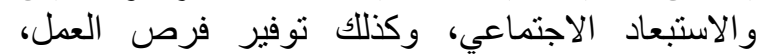

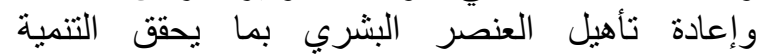

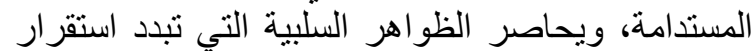

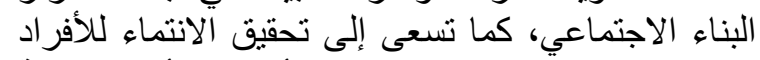

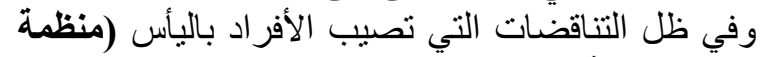

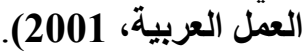

وتعرف برامج الحماية الاجتماعية على أنها سياسات

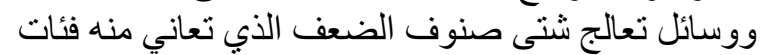

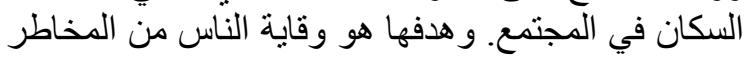

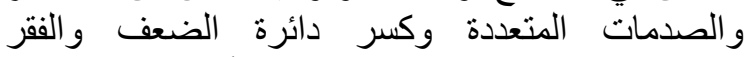

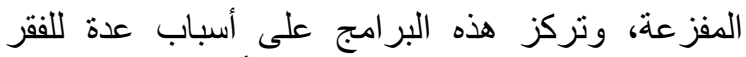

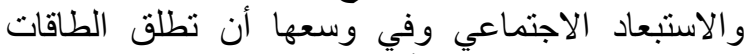

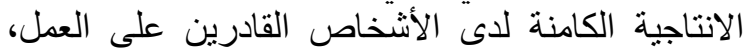
وثمة حوار مستمر بشأن حدود سباسات الحماية الاجنماعي الإني (برنامج الأمم المتحدة الإنمائي، 2010).
تطوير العشوائيات، 2013). ويثنير تقرير الأمم المتحدة للتنمية البشرية عام 2007 أن مصر تقع في التئية المركز 111 على قائمة الدول الأكثر فقراً (سليمان، 2008).

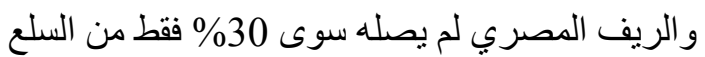

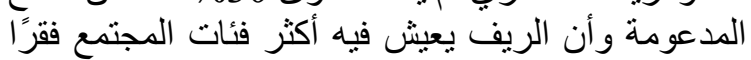

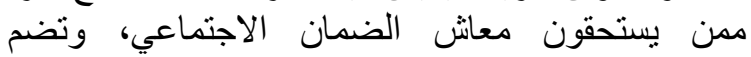
العشو ائيات ما يقرب من 12 مليون شخص ئنس يعأنون الفقر.

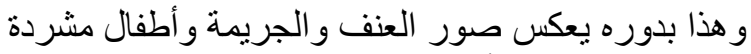

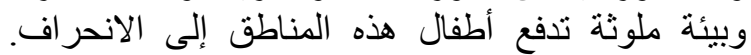

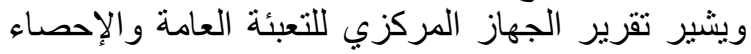

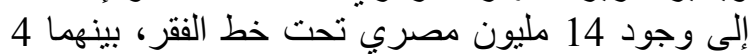

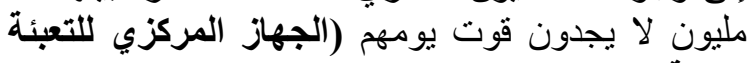

العامة و الإحصاء، 2017).

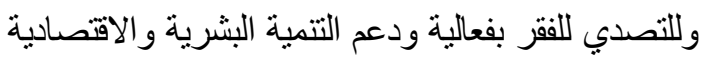
على المستوى القومي، فمن الضروري إلفية إصلاح الحماية

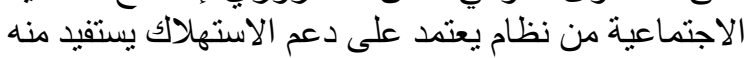
الأغنياء بالأساس إلى نظام التحويلات النقدية يستهدف الفئل الفقر اء

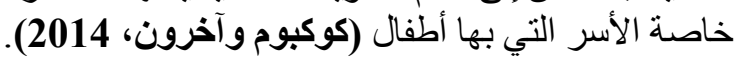

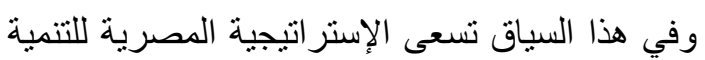

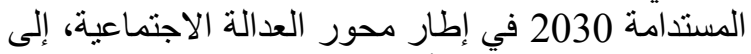

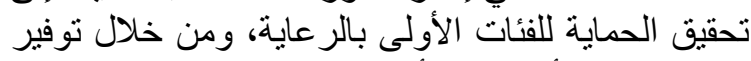

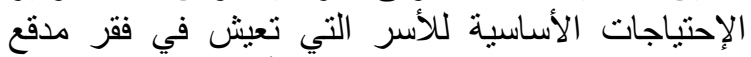

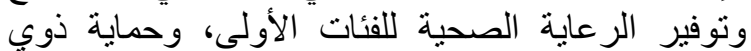
الإحتباجات الخاصة وتوفير عمل لالئ لائق مستمر للفقراء

ومحدودي الدخل (العشري، 2020).

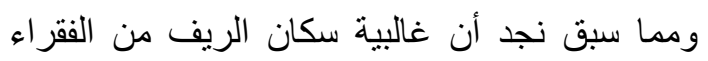

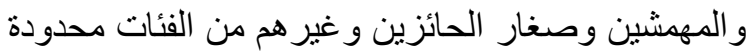

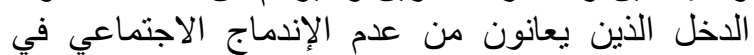

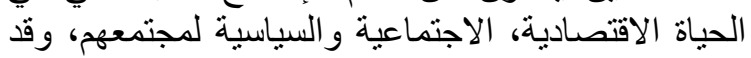

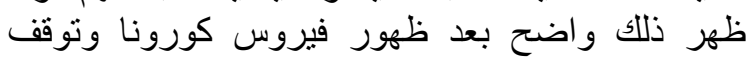

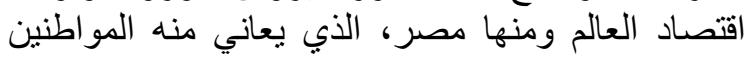

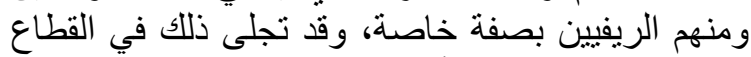

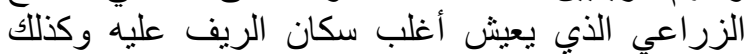

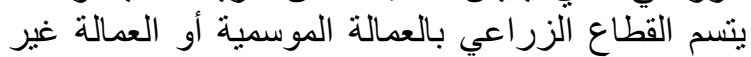

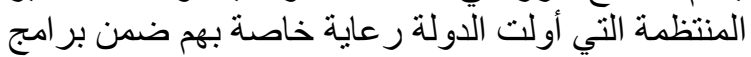

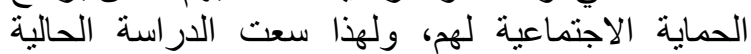
لمعرفة أساليب الحماية الاجتماعية للأسرة الريفية لإلية الراية بمحافظة الإسماعيلية.

ومن هنا انطلقت مشكلة البحث في محاولة للإجابة

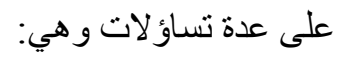
1-ما هو مفهوم الحماية الاجتماعية من وجهة نظر

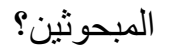

2-ما هو مستوى استفادة الأسر الريفية من أساليب الحماية الاجتماعية بمنطقة البحث؟ الانئ 
تتعرض لمخاطر كبيرة وتهدف إلى حمايتها من نتائج

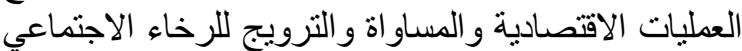

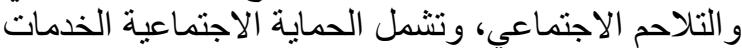

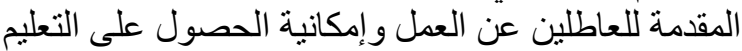

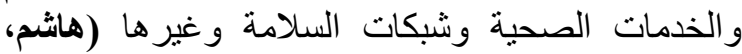

. (2014

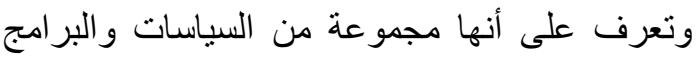

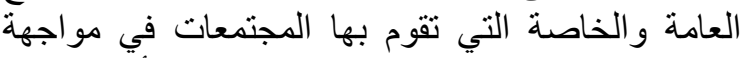

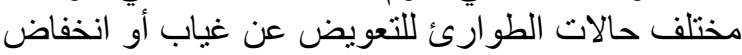

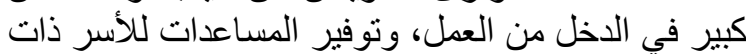
الأطفال، وكذللك تزويد الناس بالر عاية الصحية والإنيا لإسكان

.(Bhalla and Laperyre, 2004)

ويعرف شوشان (2008) الحماية الاجتماعية بأنها

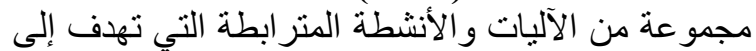

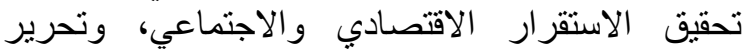

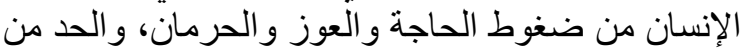

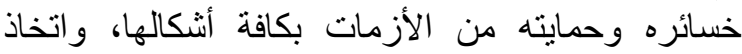
التدابير التي تؤهل الإنسان للحصول على الأنى احتياجاته

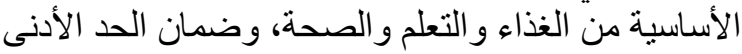

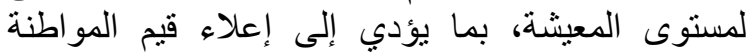
و إذكاء روح التكافل الاجتماعي وترسيخ الثعور بالانتماء.

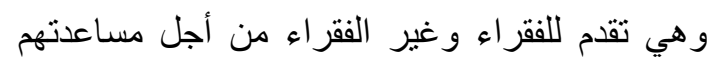

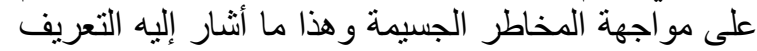

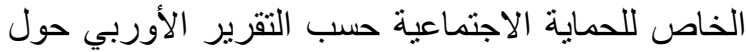

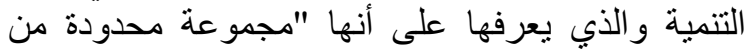

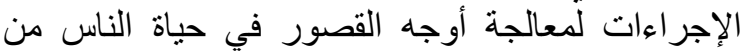

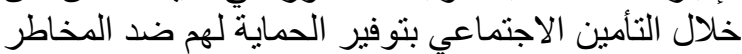

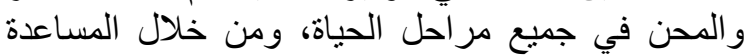

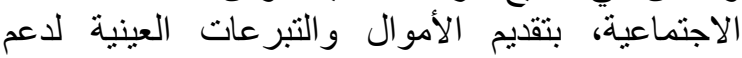

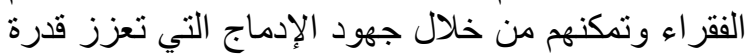

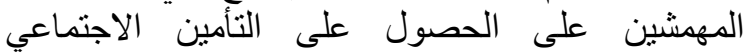
و المساعدة الاجتماعية (هاشم، 2014).

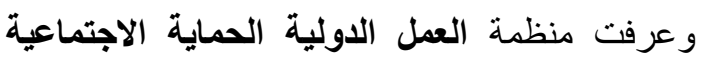

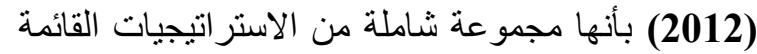

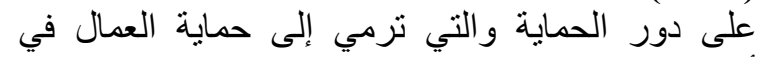

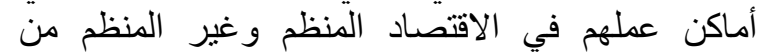
ظروف العمل غير العادلة والخطرة وغيرة التير الصحية،

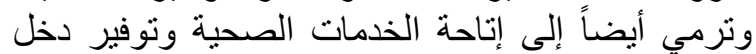

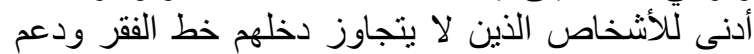

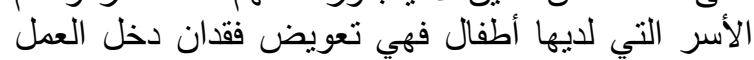

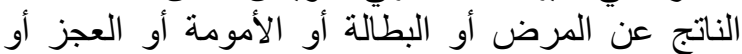
فقدان عائل الأسرة أو الثنيخوخة.

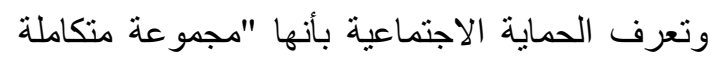

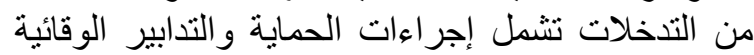
و التعزيزية و التمويلية (Aven, 2009).

$$
\text { وتنتهدف إجر اءات الحماية ما يلي: ولئية }
$$

ولكن بشكل عام تتألف الحماية الاجتماعية من ثلاث

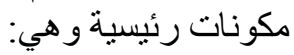

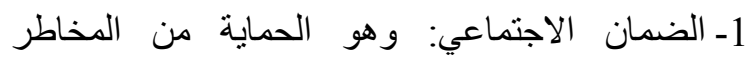

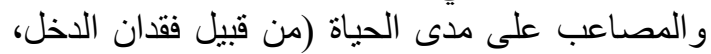

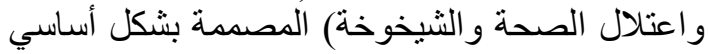
للحيلولة دون وقوع العاملين النظاميين وغير الفئل الفقراء في الفقر وتثنمل البر امج القائمة على الثتر اكات وغير وغير الفير قائمة على اشتر اكات.

2- المساعدة الاجتماعية: وهي تحويلات اجتماعية نقدية

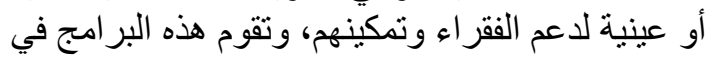

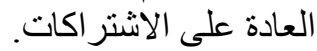

3- جهود الإدماج وسياسات سوق العمل: وهي مصممة الإنة

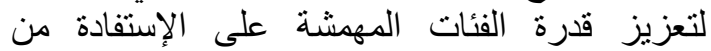
الخدمات و والبرامج الاجتماعبة، و الالتحاق بأسواق القان

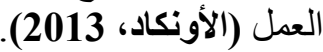

وأدت الأزمة الاقتصادية العالمية ما بين عامي الإني

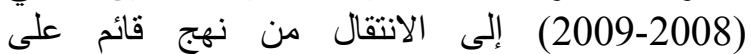
الإحتياجات إلى آخر قائم على الحقوق في مجال الحماية

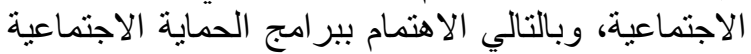

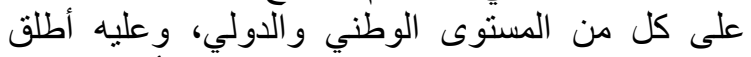

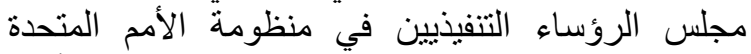

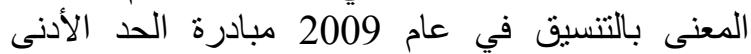

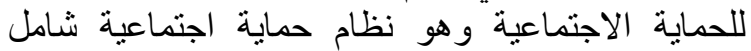

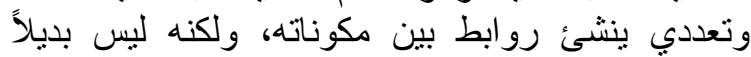

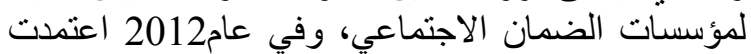

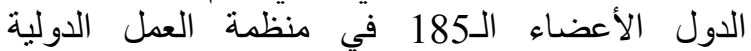

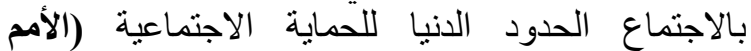

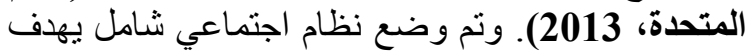

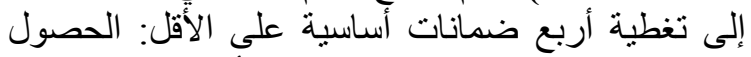

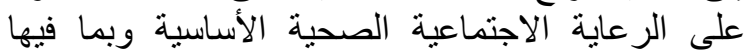

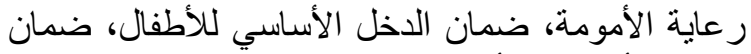
الدخل الأساسي للأشخاص في سن سن العمل غيل الإنير القادرين

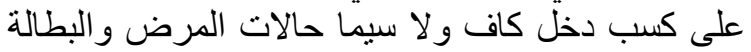
و الأمومة والعجز، الضمان الدخل الأساسي لكبار السن.

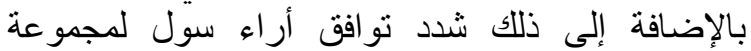

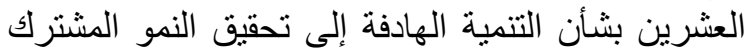

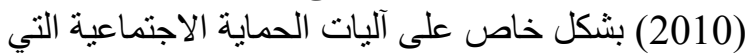

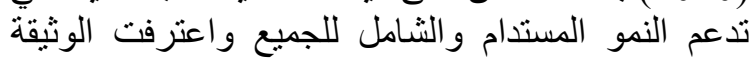

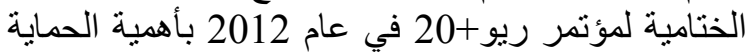

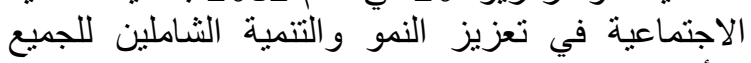

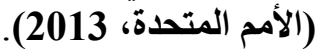

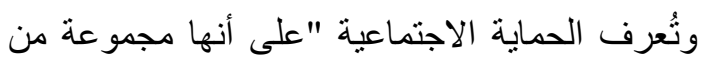

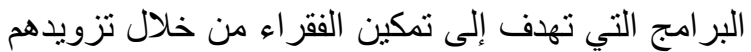

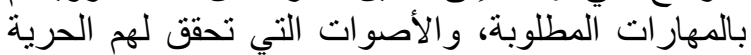

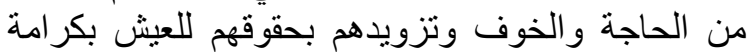

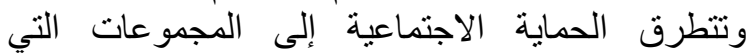


الآثار السليية المحتملة على الطبقات الفقيرة والهثة

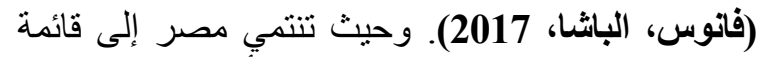
الدول التي تقع ضمن الحد المتوسط الأدنى للاخل، وئل ويبلغ

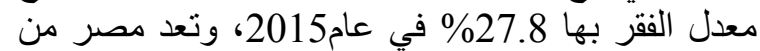

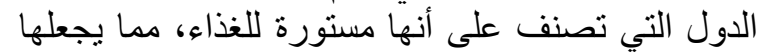

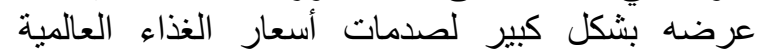

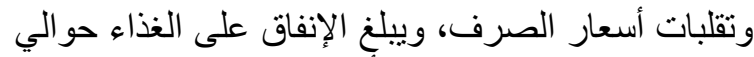

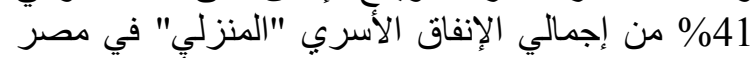
ترتفع هذه النسبة إلى 51\% الإفى بين العشير الأفقر. ومن ثم

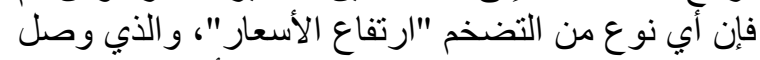

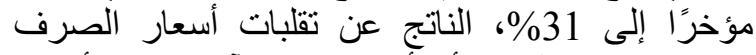

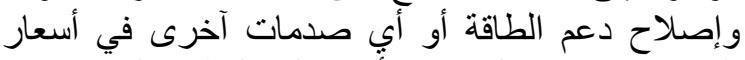

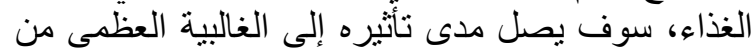

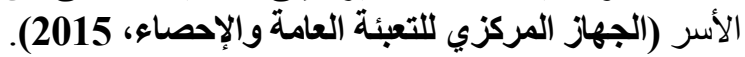

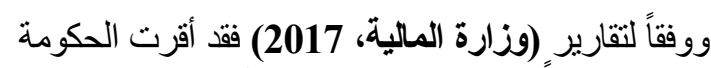

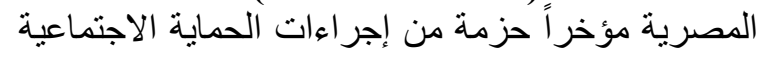

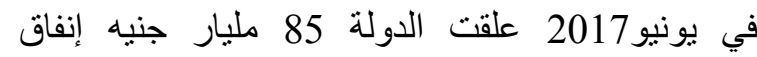
اجتماعي تم توزيعه على بنود النيو إنفاق الحماية الاجتماعية

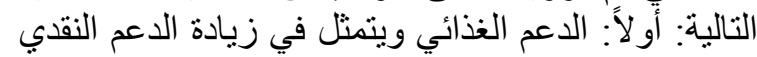

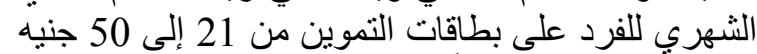

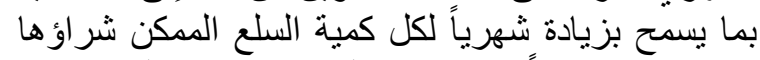

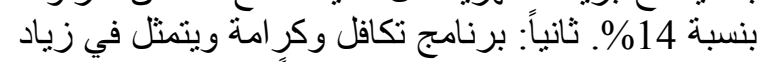

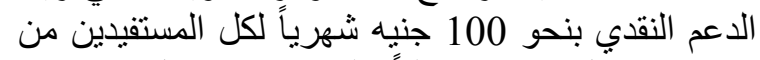

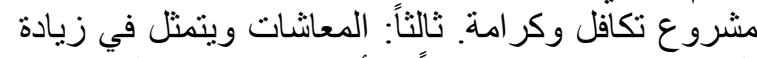

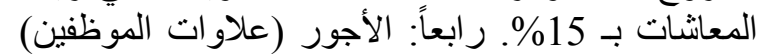

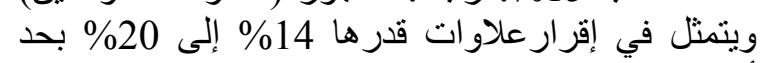

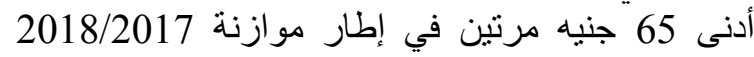

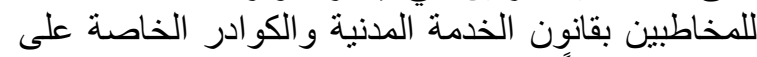

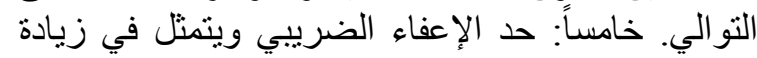

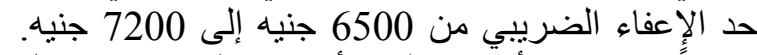

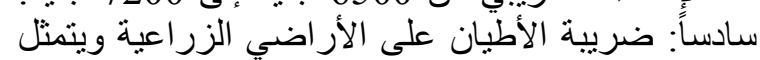

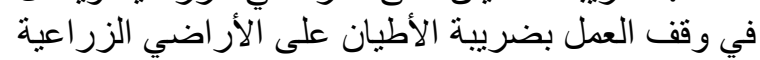

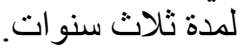

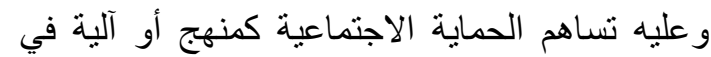

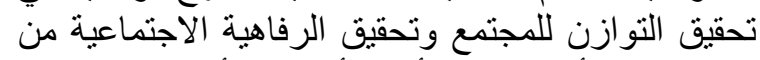

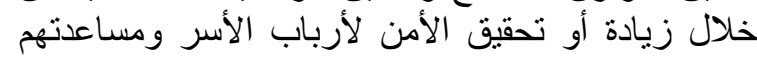

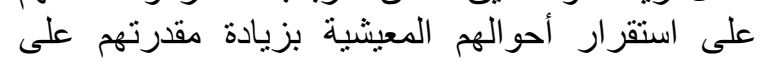

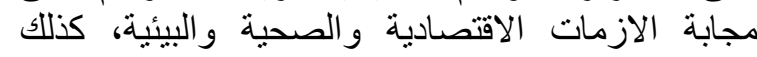

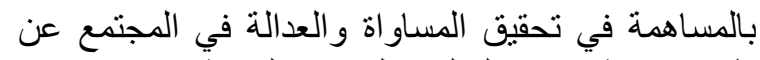

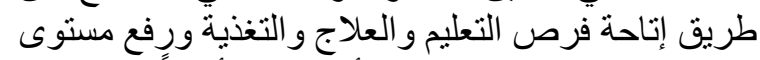

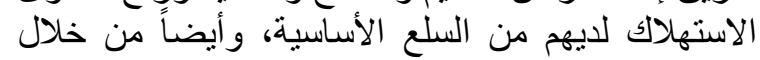

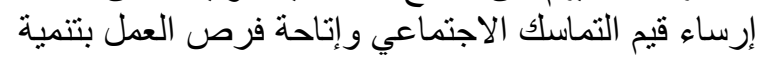

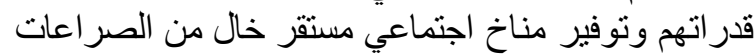
و النزاعات بين فئات المجنمع (Norton, 2001).

وتتطلق الدراسة الحالية من نظريات الحاجات الإنسانية

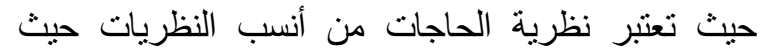
ينطلق البحث الحالي من نظرية ماسلو للحاجات الإنسانية،
1- شبكات الأمان للاخل والاستهلاك في تجانس فترات

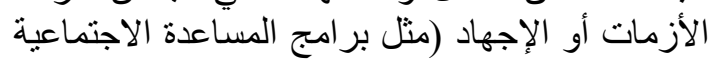

$$
\text { للفقر اء الذين يعانون من فقر مزمن). }
$$

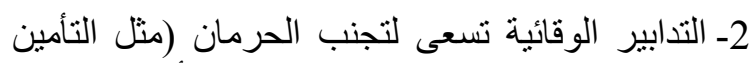
الاجتماعي و المعانشات مثل استحقاقات الأمومة)

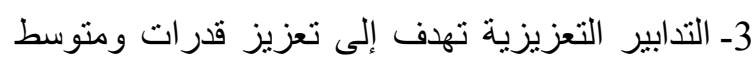

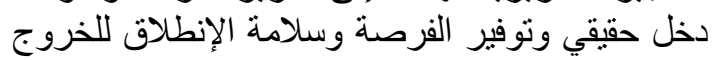
من بر اثين الفقر.

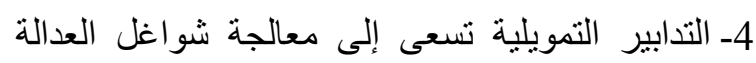

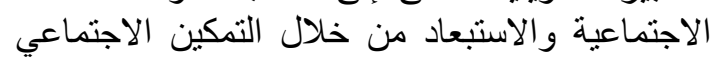

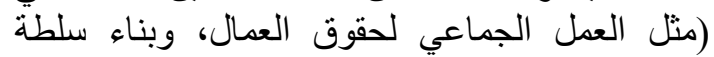
وصوت في صنع القرار بالنسبة للمرأة) (مركز بصيرة المياء لبحوث ودراسة الر أي العام، 2014). وأجمع الباحثون على أن لنظم الحماية الاجتماعية الحديثة وظيفتان أساسيتان هما:

\section{وظيفة مظلة الأمان}

التي ينبخي أن تتضمن تزويد كل فردم من الأن أفراد

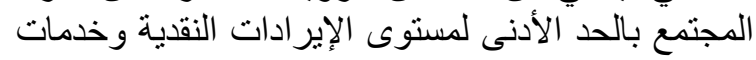

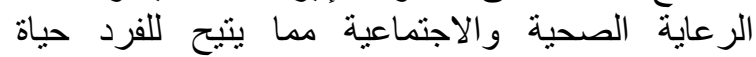

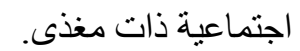

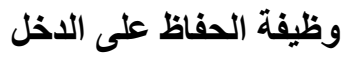

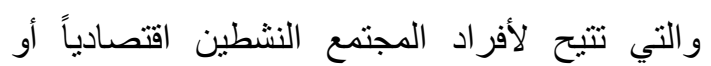

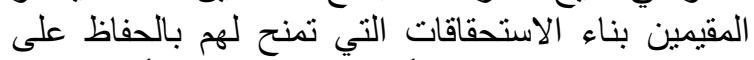

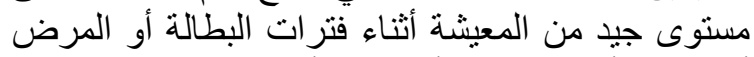

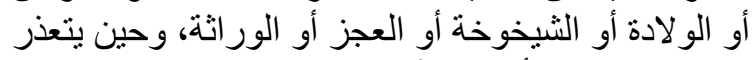

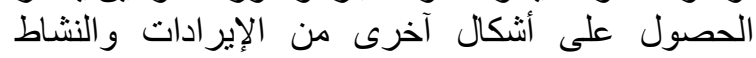

(عوض، 2014).

ويرى البعض أن الحماية الاجتماعية لها جانبان هما:

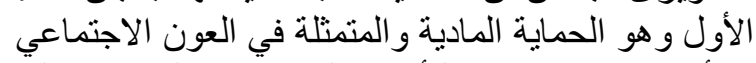

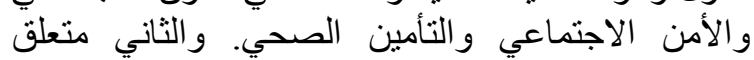

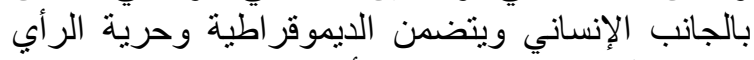

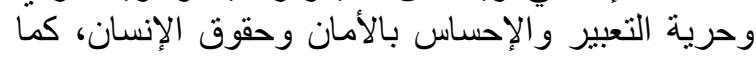

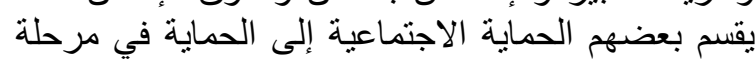

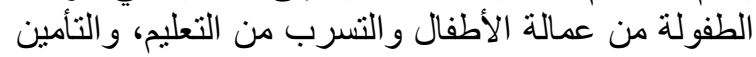

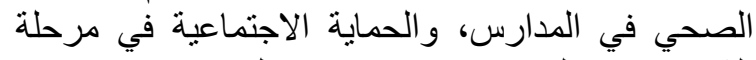

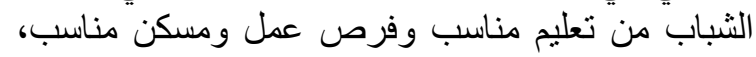

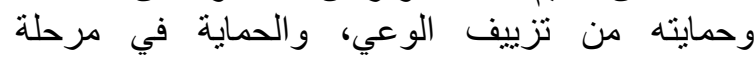

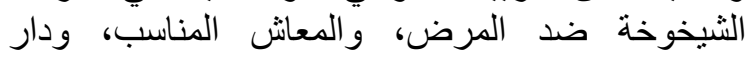

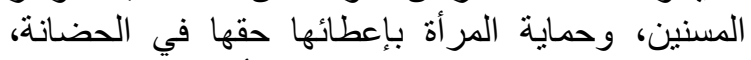

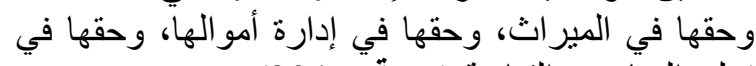
تولي المناصب القيادية (وهبة، 2017)

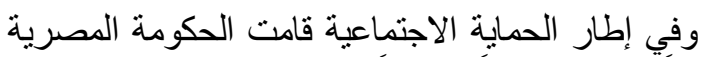

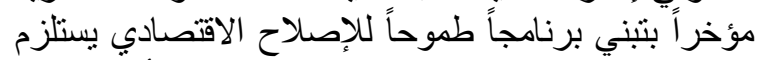

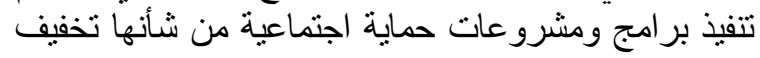


وفي دراسة فانوس والباشا (2018) نوصل الباحثان

إلى أن إدراك الريفيين لمفهوم الحماية الاجتماعية بمنطقة البكائة

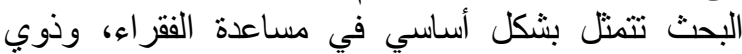

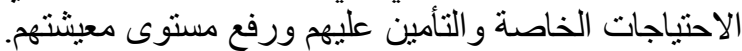

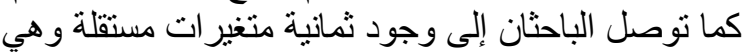

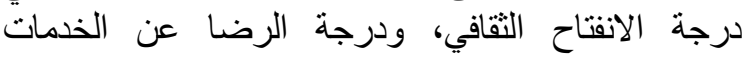

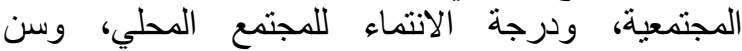

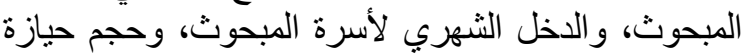

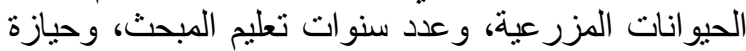

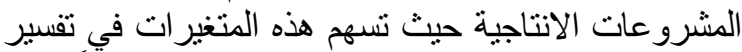

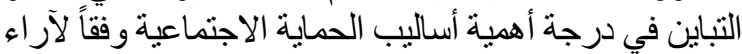
أرباب الأسر، حيث بلغت نسبة الإسهام نحو 36\% من

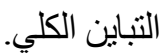

وفي دراسة وهبة وآخرون (2017) نوصل الباحثين إلى أن أكثر آليات الحماية الاجتماعية المتعلقة بالاحتياجات

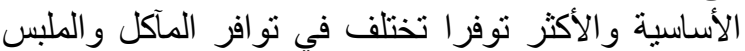

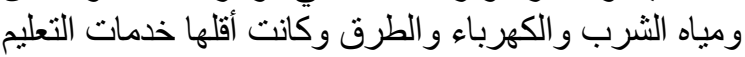

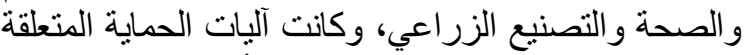

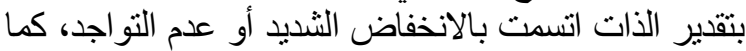

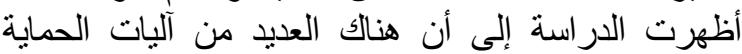

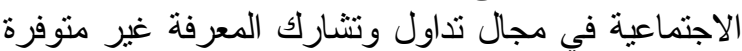

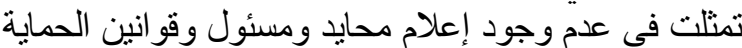

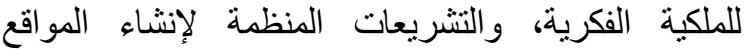

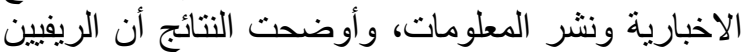

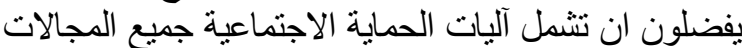

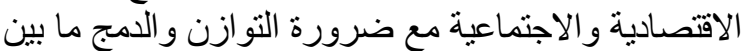

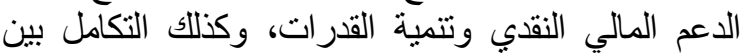

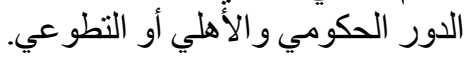

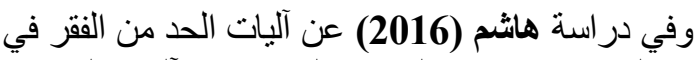

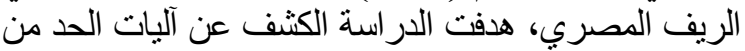

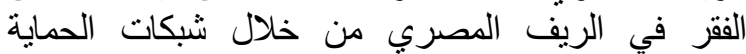
الاجتماعية وأنثكال الحماية الاجتماعية التي تعمل بالريف

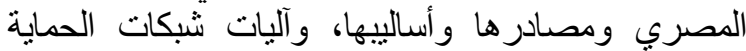
الاجتماعية في الحد من الفقر داخل المجتمع من أجل معالجة آلئل

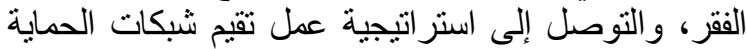
الاجنماعية لتوحيد الجهذ من أجل الحد من الفقر والكثئف

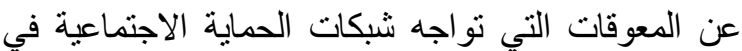

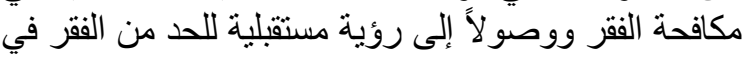

مصر.

وتوصل هاثم (2015) في دراسته أن مصر تتخذ الأند العديد من الأشكال والآليات للحماية الاجتماعية بهدف

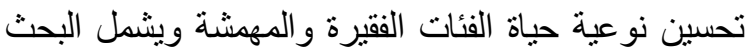

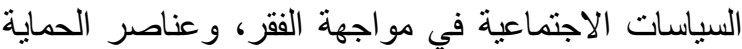
الاجتماعية، وآليات الحماية الاجتماعية وما تضمنه الحية الدستور

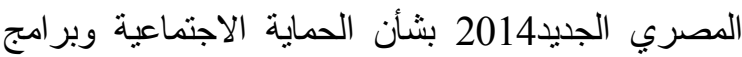

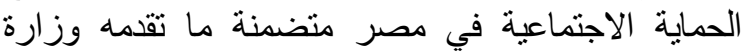
الثئون الاجتماعية والصندوق الاجتية فئماعي للتنمية، وصولاً
وهي نظرية سلوكية يمكننا من خلالها أن نعرف طبيعة

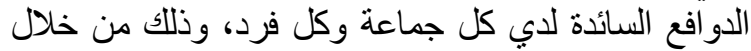
معرفة الظروف التى يعيشها الفرد أو الجماعة (العبيدي، وذئ

.(2009

ويري ماسلو أنه يوجد العديد من الحاجات لكل انسان

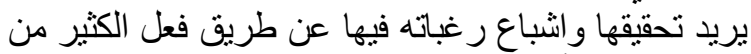

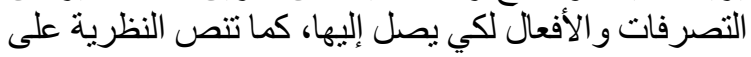

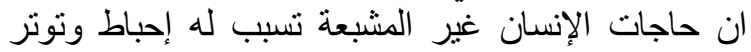
وآلالام نفسية حادة، و أنه يجب إلثبان الثباع الحاجات الدنبا قبل الثبل

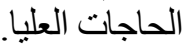

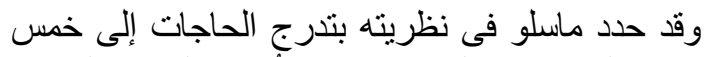

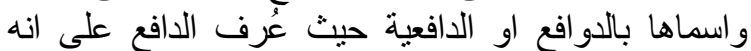

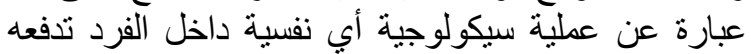

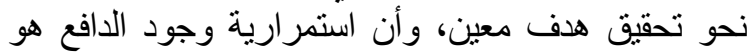

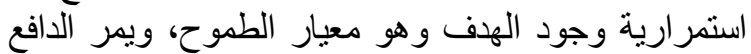

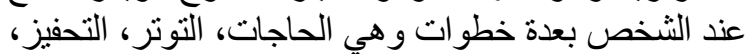

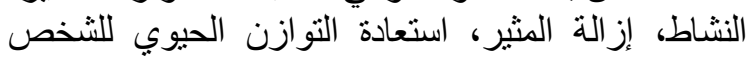

(مصطفي، 2015).

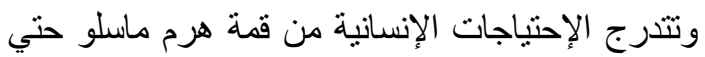

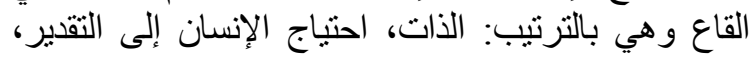

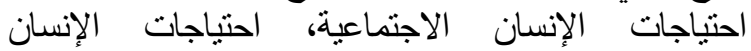
الاجتماعية، احتياجات الإنسان إلى الأمان احتباجيات الإنيات الإنسان

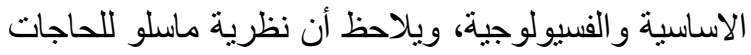

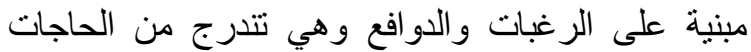

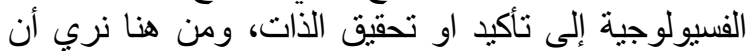

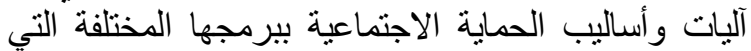
توجه الريفيين هي عملية اثباع للرغباتيات الريفين الريبين الفقراء

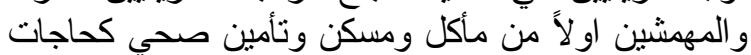
اولية ثم تنظر النظرية الي احتياجات الإنسان آلي الأمان

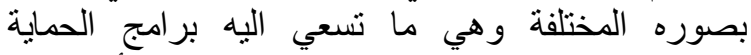

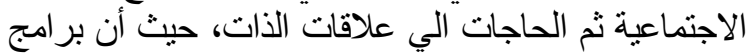

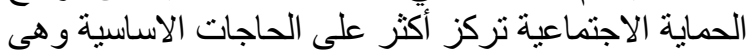

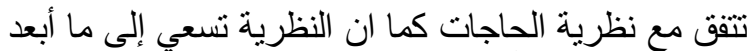

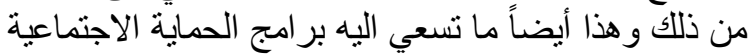

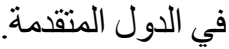
الاراسات السابقة

في دراسة حسن (2018) نوصل إلى أن آليات الحماية

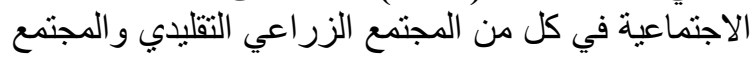

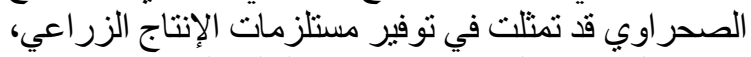

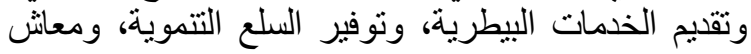

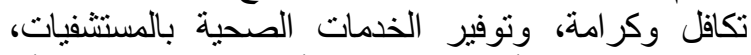

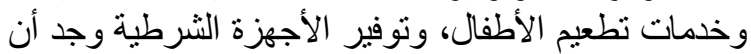

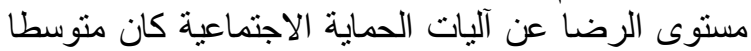

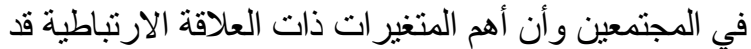
تمثلت في سن المبحوث، ودرجة المشاركة الاجنماعية الهية

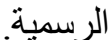


لا توجد علاقة معنوية بين المتغيرات المستقلة

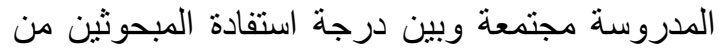
أساليب الحماية الاجتماعية كمتغير تابع.

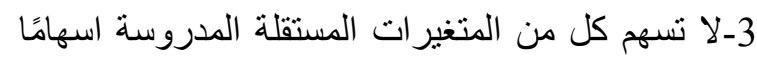

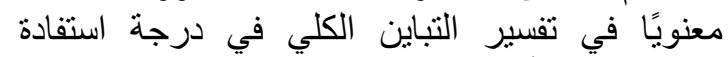
المبحوثين من أساليب الحماية الاجنماعية كمتغير تابع.

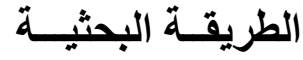

منطقة البحث

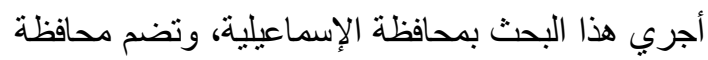

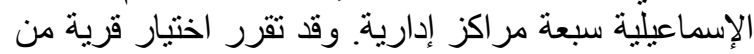
كل مركز، و القرى المختارة هي القرى الأكثر احتياجًا بكل

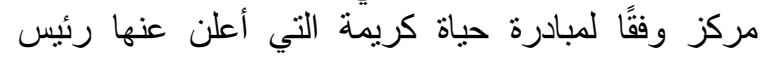

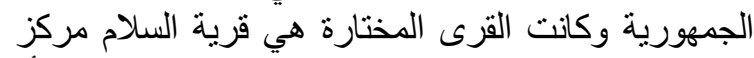

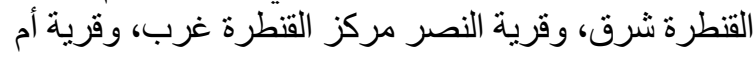

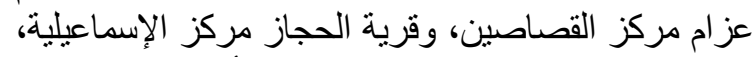

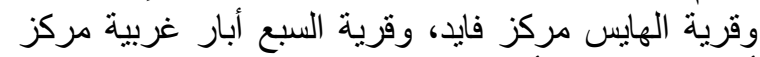

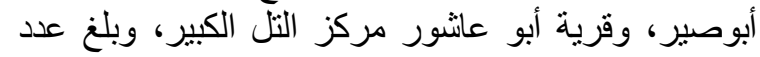

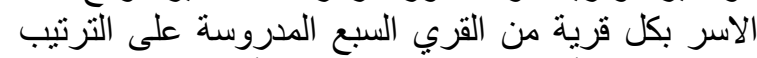

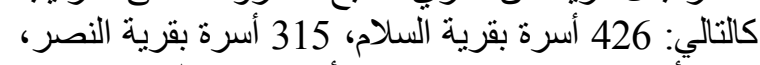

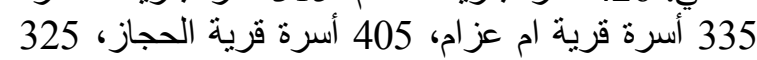

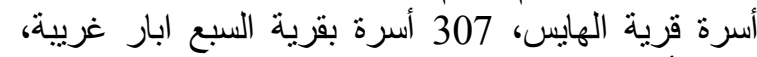

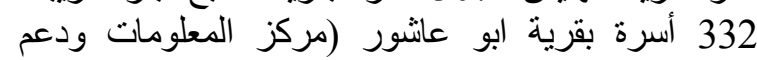

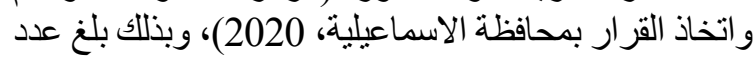
الاسر بالقري السبع المدروسة 2450 أسرة ريفية اعتبرت وبلغ علئ

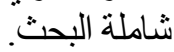

شاملة البحث وعينته

بلغت شاملة البحث 2450 أسرة ريفية وقد تقرر أخذ البذانه

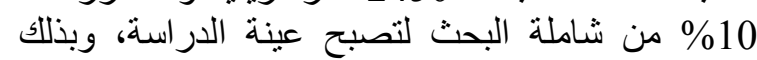

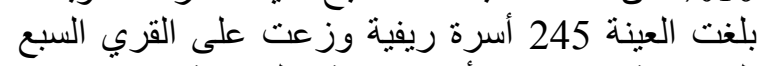

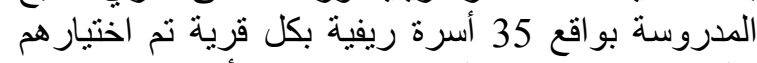

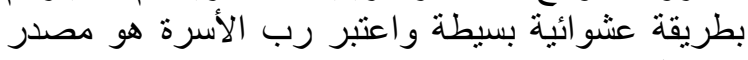
جمع البيانات.

\section{أسلوب جمع البيانات}

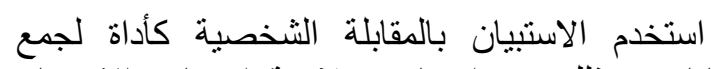

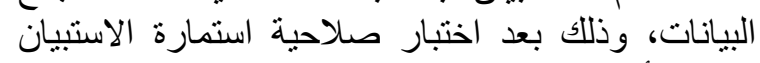

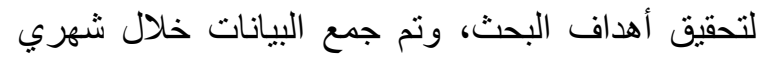

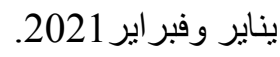
قياس المتغيرات البحثية المتغيرات المُستقلة

1-سن المبحوث: تم قياساه بسؤال المبحوث عن سنه وقت وتهرت

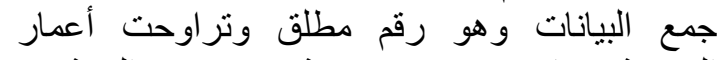
المبحوثين ما بين (31-66) سنة وتم تقسيمه إلى ثلاث
إلى رؤية مستقلية، حيث توصل البحث إلى أن هنالك خطوات إتاتية

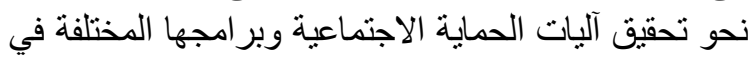

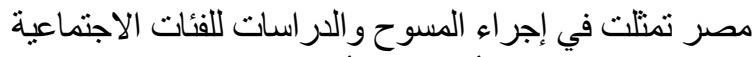

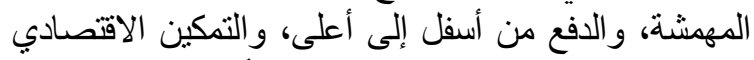

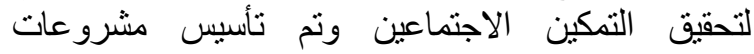

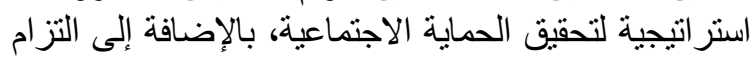
الدولة بتحقيق الحماية الاجتماعية للفقر اء و المهمشين.

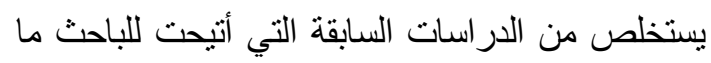
يلي:

1- أنه يوجد ندرة في إجراء الدراسات التي أجريت في هذا الموضوع. - (أنه بوجن نرة

2- أن جميع الدراسات ركزت على ألى أساليب وبر امج الحماية

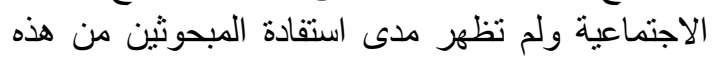

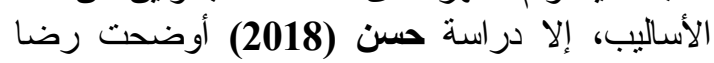
المبحوثين عن أساليب الحماية الاجتماعية.

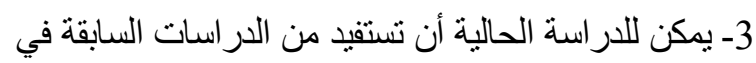

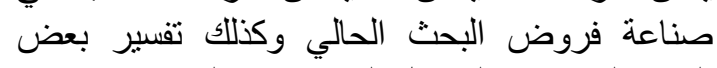

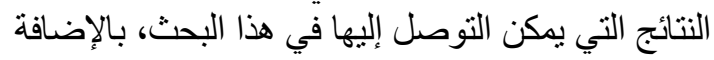

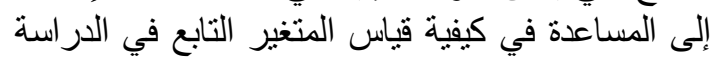

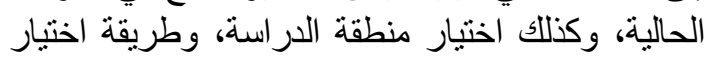
العينة وحجمها.

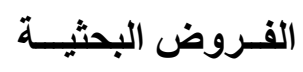

1- توجد علاقة معنوية بين درجة استفادة المبحوثين من النائ

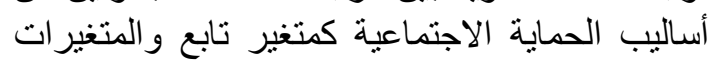

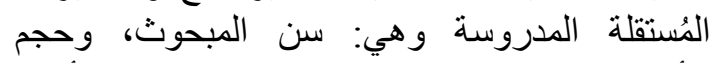
الأسرة، والدخل الثهري، والثدرئ وعدد غير العاملين بالأسرة

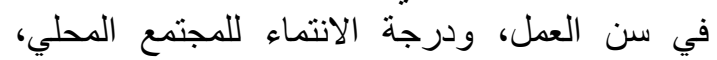

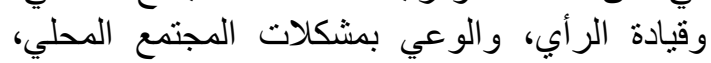

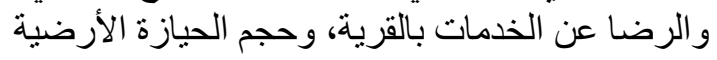
الزر اعية، وحجم الحيازة الحيو انية.

2- توجد علاقة معنوية بين المتغيرات المُستقلة المدروسة المبنة مجتمعة، وبين درجة استفادة المبحوثين من المئنين أساليب الحماية الاجتماعية كمتغير تابع.

3- تسهم كل من المتغيرات المُستقلة المدروسة إسهاماً

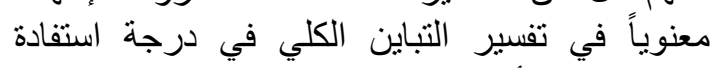
المبحوثين من أساليب الحماية الاجتماعية كمتغير تابع.

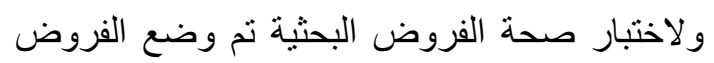
الإحصائية المناظرة لها في صورتها الصفرية كالتالي:

1- لا توجد علاقة معنوية بين درجة استفادة المبحوثين من الإنية

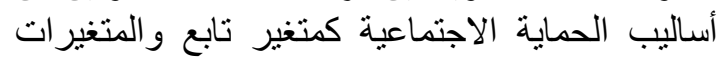
المستقلة المدروسة. 
المسئولة عن حل هذه المشكلات، والبعد الثالث معرفة

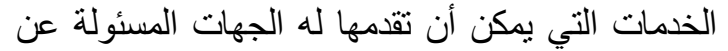

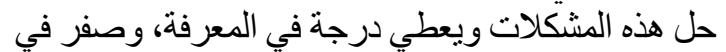

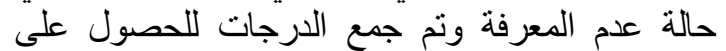

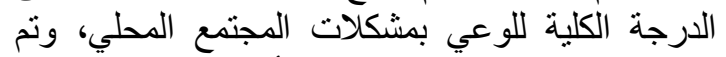

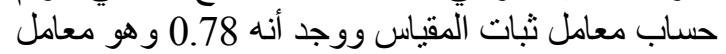

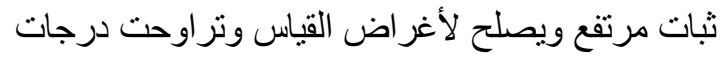
المبحوثين على هذا المقياس ما بين (3-8) درجة.

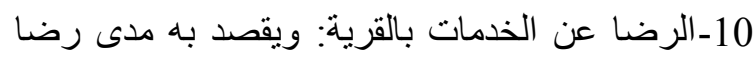

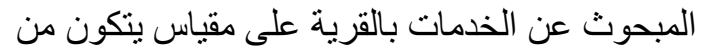

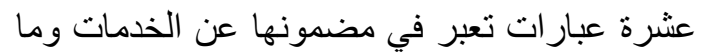

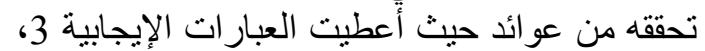
2، 1 و السلبية 1، 2، 3 وكان استجابات المبحوثين الإبين

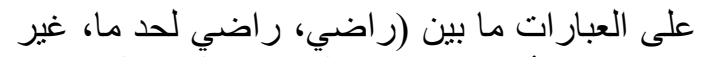

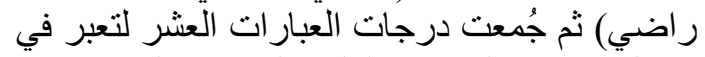

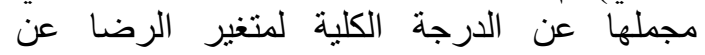

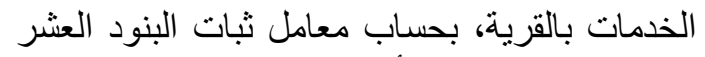

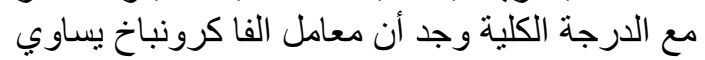

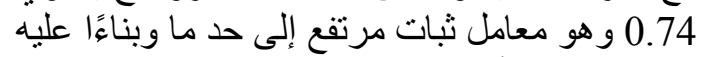

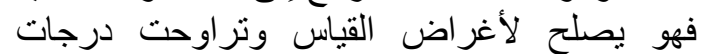
المبحوثين ما بين (10-30) درجة.

\section{قياس المتغير التابع: أساليب الحماية الاجتماعية}

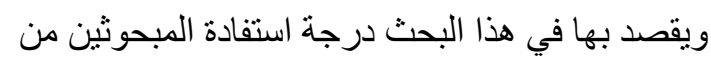

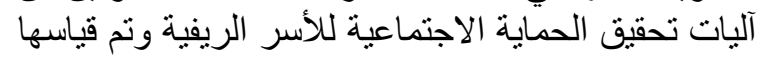

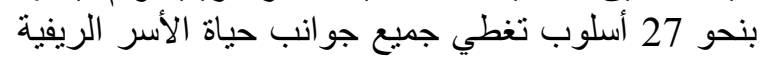

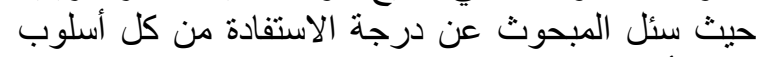

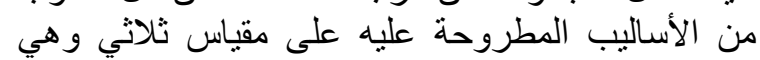

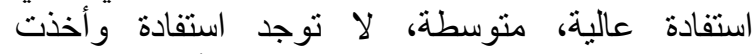

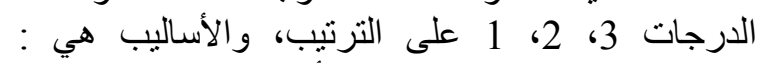
المساعدة الاجتماعية للفقراء، التأمين الصحي والتحي للريفيين،

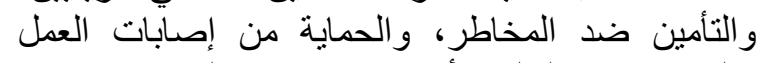

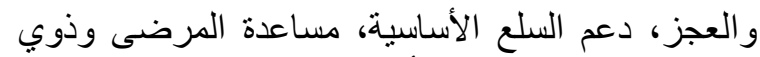

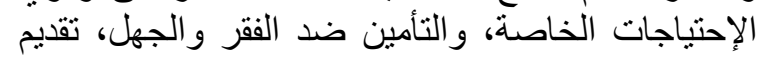

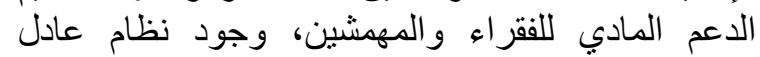
لإيجار الأراضي الزراعية، العدالة في توزيع الأراضي وتئي

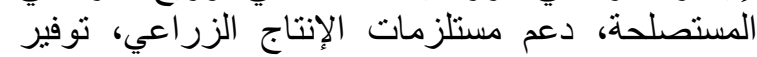

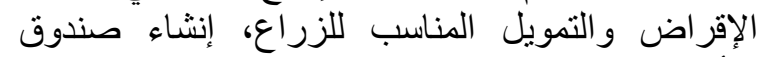

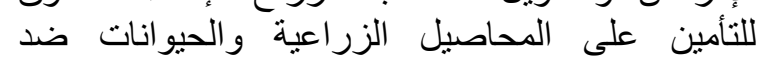

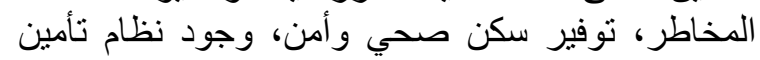

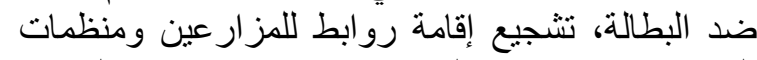

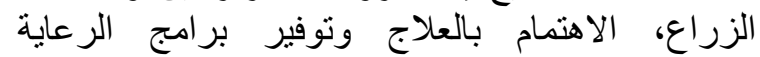

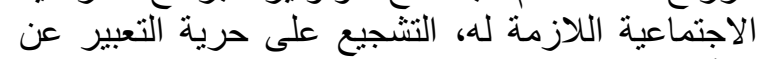

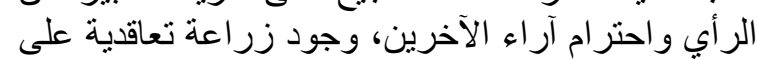

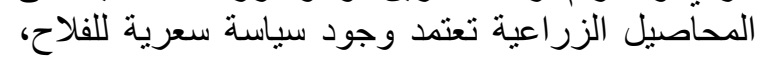

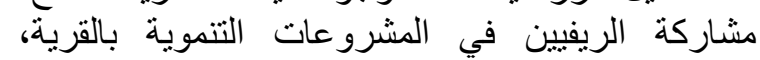

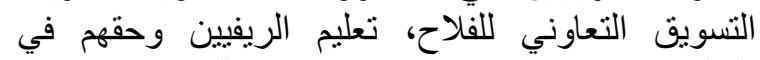
التعليم، تحقيق الاستقرار الاجتماعي للريفيقين ولرين وعلاج
2-حجم الأسرة: وتم التعبير عنه بعدد أفراد أسرة المبحوث كرقم خام، وتر اوح عدد أفريز أفر اد أسرة المبحوث

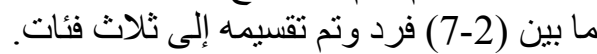

3ـ الدخل الثهري للمبحوث: نم الحصول عليه كرقم خام، وتراوحت دخول المبحوث المبحثين ما بين (1400-7500) جنيه وتم تقسيمه إلى ثلاث فئات.

4- عدد أفر اد الأسرة غير العاملين في سن العمل: ويقد إلهد

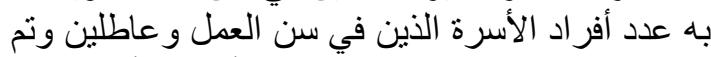

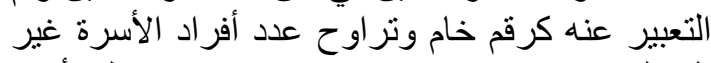
العاملين ما بين (صفر - 3) فرد وتم وتم تقسيمه إلى أربع

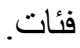

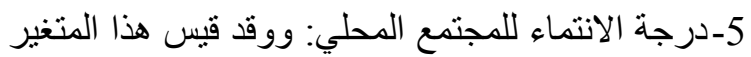

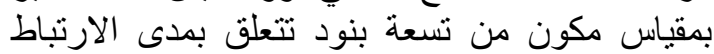

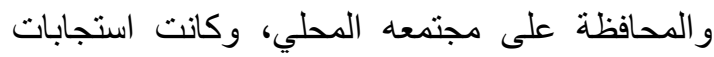

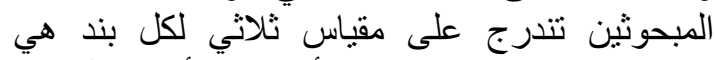

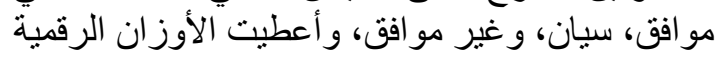

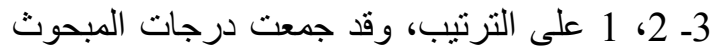

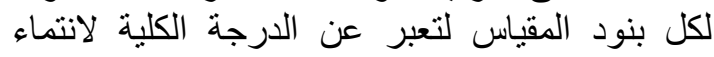

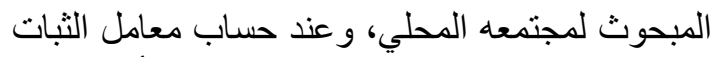
لهذه البنود التسعة مع الدرجة الدئ والكلية وجد أنها 0.72

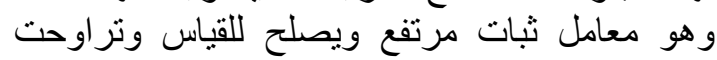

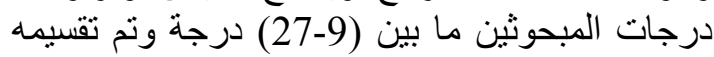

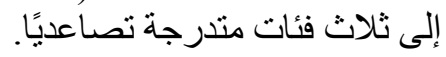

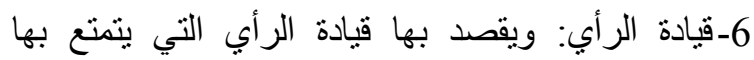

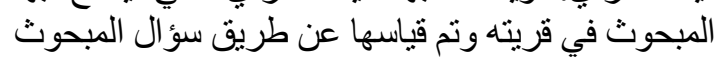

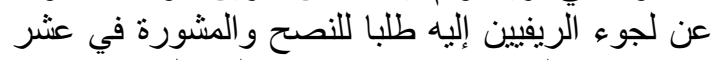

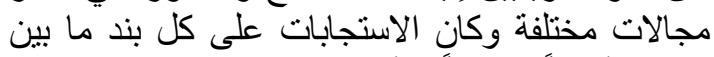

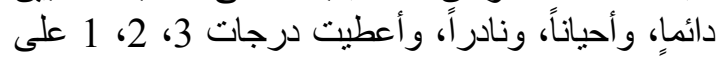

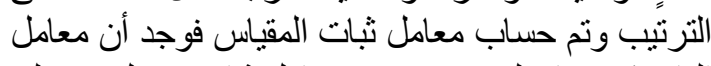

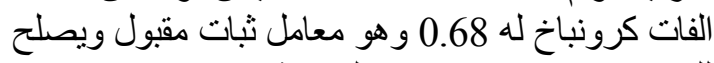

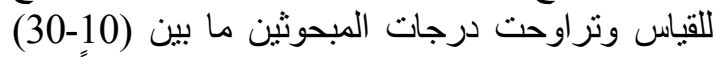

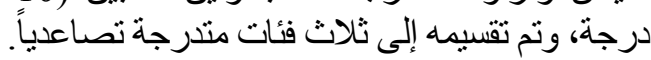

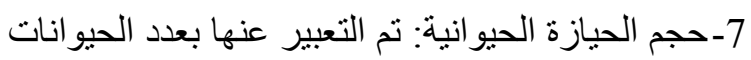

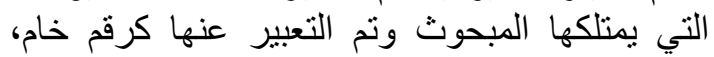

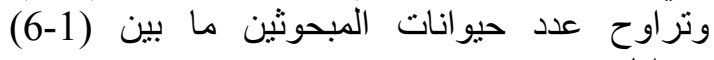
حيو انات. ت متراح

8-حجم الحيازة الزراعية: نم قياسها بعدد القراريط التي

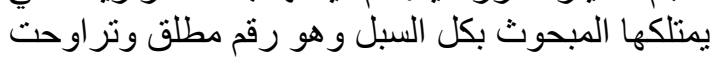
الحيازة الزر اعية ما بين (صفر -230).

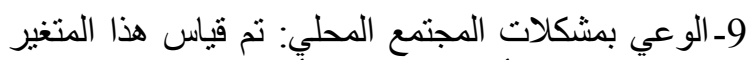

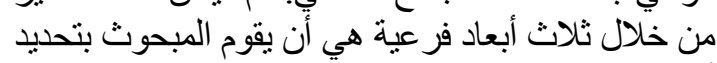

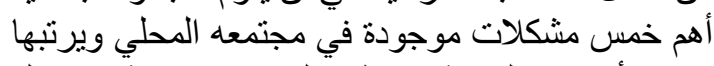

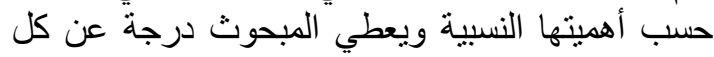

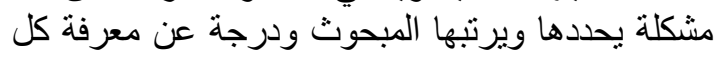
جهة تحل له المشكلة، والبعد الثاني أن يحدد الجهات 
الاجتماعية يتر اوح ما بين (27-81) درجة وتم تقسيم هذا

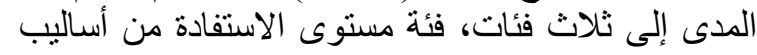

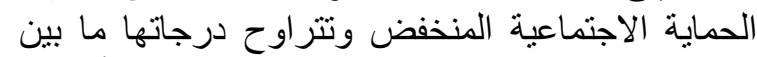

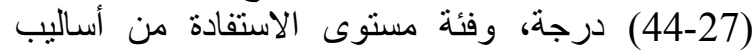

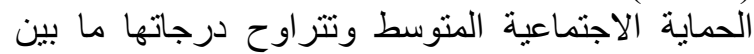

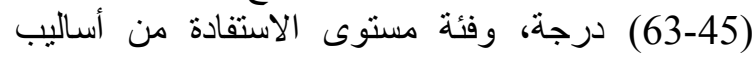

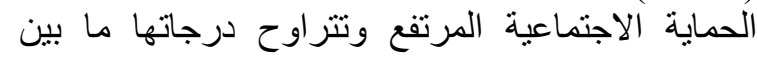

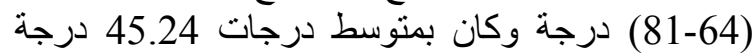

$$
\text { و انحر اف معياري قدره } 2.1 \text { درجة درنة. }
$$

ويُّاحظ من جدول 2 أن نحو الريفية تقع في مستوى الاستفادة من الحماية الاجتماعية الإنية

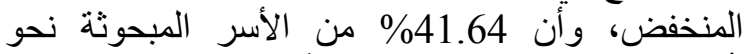

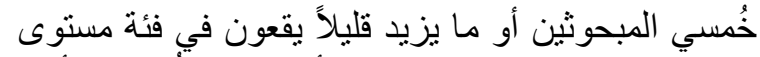

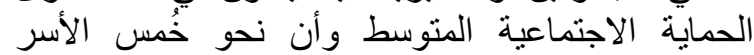
المبحوثة 19.59\% يقعون في الفئة المرتفعة.

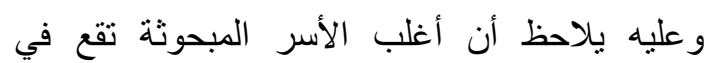

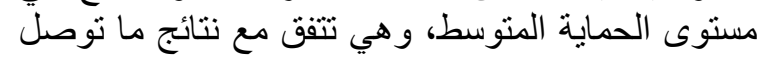

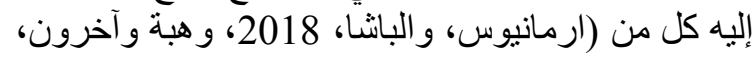

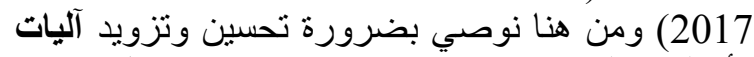

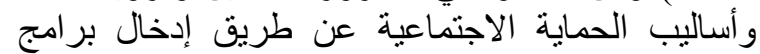

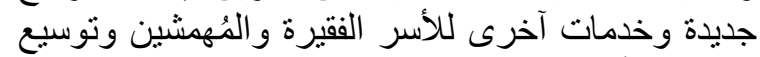

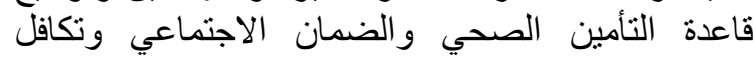
وكر امة لكل المحتاجين.

\section{معنى مفهوم الحماية الاجتماعية من وجهة نظر الريفيين المبحوثين مغوم المثائ}

يعرض جدول 3 معنى مفهوم الحماية الاجتماعية كما

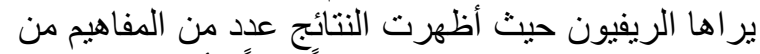

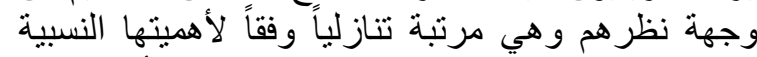

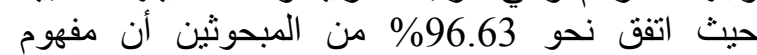

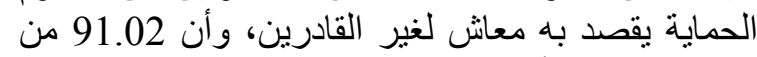

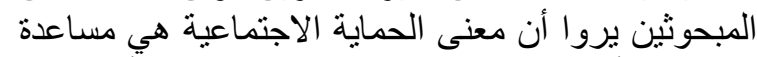

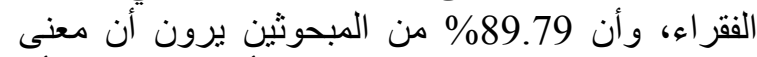

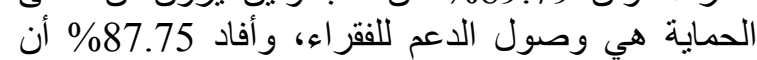

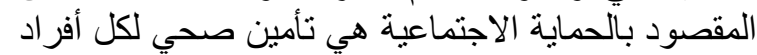

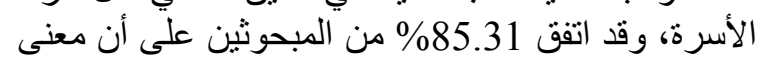

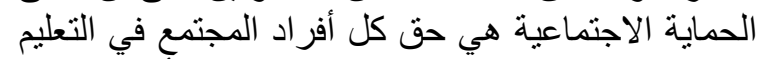

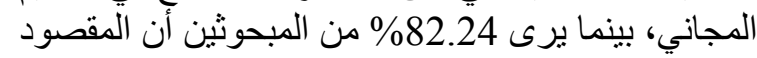

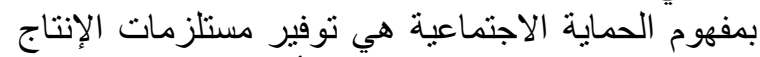
للزر اع، بينما يرى 77.14\% من الأن أن الحماية الاجتماعية

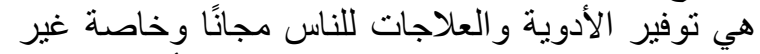

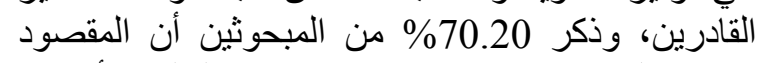
بمعنى الحماية الاجتماعية هي توفير المبرير السلع الأساسية

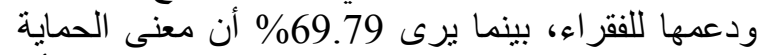

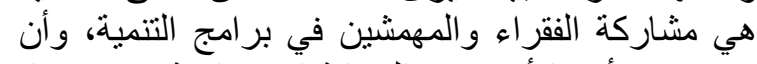

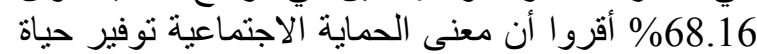

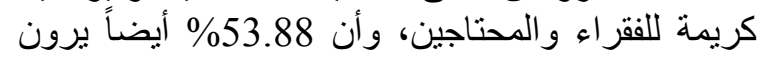

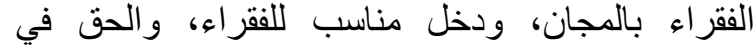

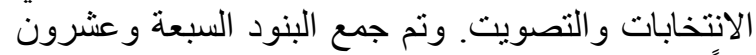

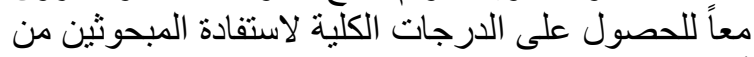

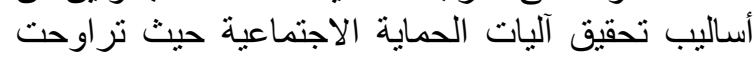

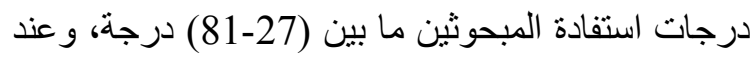

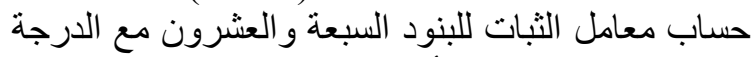

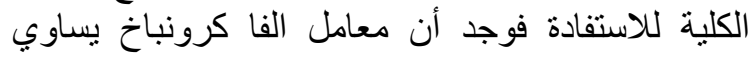
0.69 وهو معامل ثبات معقول إلى حد كبئ كبير ويصلح

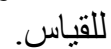

أدوات التحليل الإحصائي المستخدمة

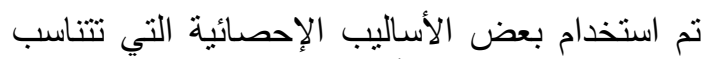

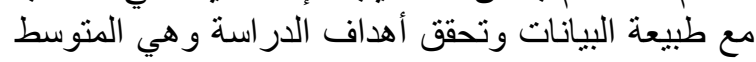

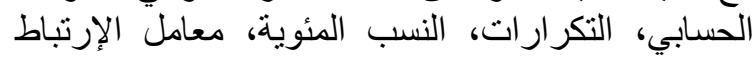

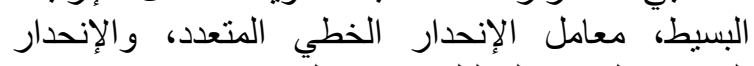
التدرجي الصاعد لتحليل وتفسير النتائج.

\section{النتائســـج ومناقشتهـا}

\section{خصائص عينة البحث}

أظهرت النتائج المعروضة بهنه بجدول 1 أن أعمار المبحوثين

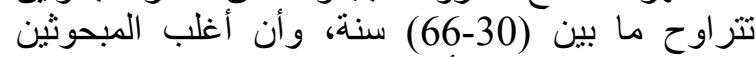

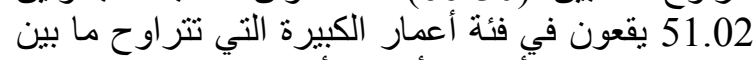

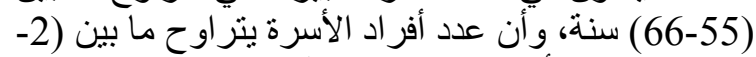

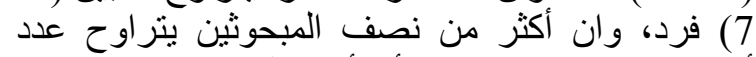

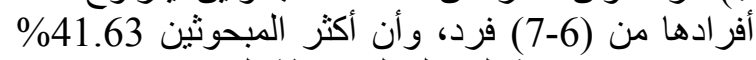

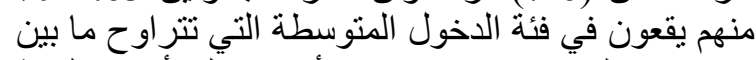

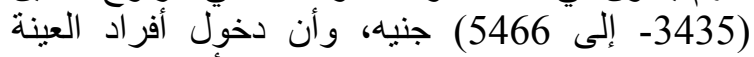

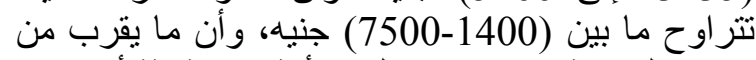

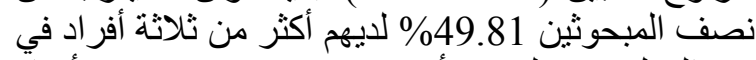

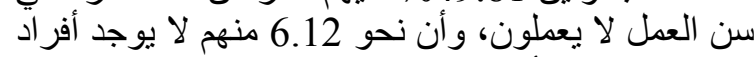

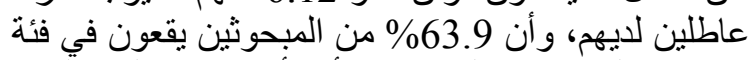

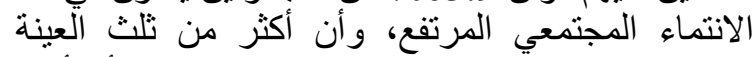

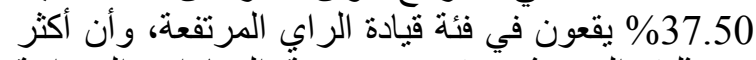

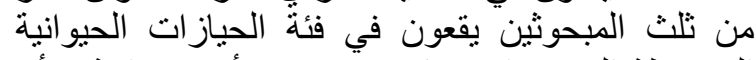

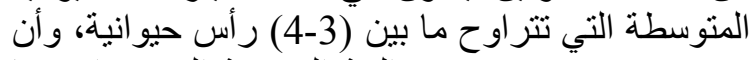

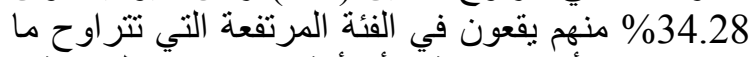

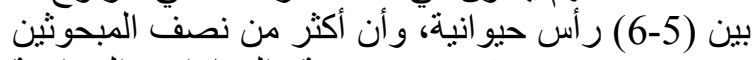

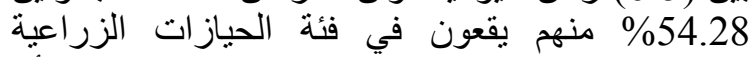

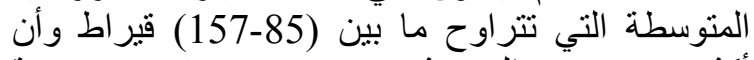

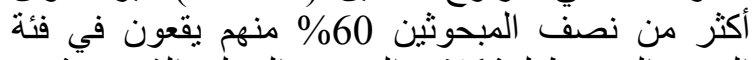

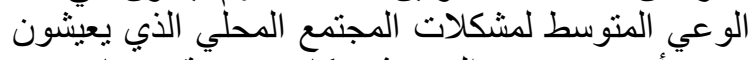

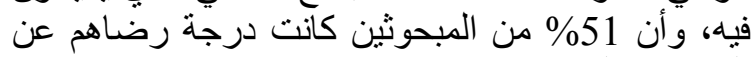
الخدمات بالقرية منخفض.

التعرف على مستوى استفادة المبحوثين من الأسر الريفية من أساليب الحماية الاجتماعية بمنطقة البحث الأبن

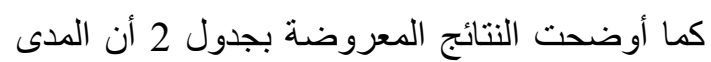

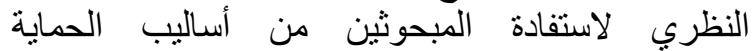


جدول 1. توزيع المبحوثين وفقًا للمتغيرات المُستقلة المدروسة.

\begin{tabular}{|c|c|c|c|c|c|}
\hline$(\%)$ & 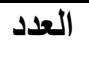 & تضغيرات المُستقلة & $(\%)$ & العدد & المتفيرات المُستقلّة \\
\hline \multicolumn{6}{|c|}{ 6- قيادة الـرأي: } \\
\hline 26.94 & 66 & المنخفضة (10-16) درجة & 20.41 & 50 & الصغيرة (42-31) سنة \\
\hline 35.51 & 87 & المتوسطة (17-23) درجة & 28.57 & 70 & المتوسطة (43-54) سنة \\
\hline 37.55 & 92 & المرتفعة (30-24) درجة & 51.02 & 125 & الكبيرة (56-66) سنة \\
\hline \multicolumn{5}{|c|}{ 7- حجم الحيازة الحيوانية: } & 2- حجم الأسرة: \\
\hline 5.31 & 13 & لا يوجـــ & 19.18 & 47 & الصغيرة (2-3) فرد \\
\hline 22.86 & 56 & المنخفضة (1-2) رأس & 27.75 & 68 & المتوسطة (4-5) فرد \\
\hline 37.55 & 92 & المتوسطة (3-4) رأس & 53.07 & 130 & الكبيرة (6-7) فرد \\
\hline \multicolumn{6}{|c|}{ المرتفعة (5-6) رأس } \\
\hline \multicolumn{5}{|c|}{ 8- حجم الحيازة الزراعية: } & 3- الاخل الثهري: \\
\hline صفر & صفر & لا يوجد حيازة & 35.92 & 88 & المنخفضة (1400-3433) جنيه \\
\hline 8.57 & 21 & صغيرة (12-84) قيراط & 41.63 & 102 & المتوسطة (5466-3435) جنيه \\
\hline 54.28 & 133 & متوسطة (157-85) قير اط & 22.45 & 50 & المرتفعة (5467-7500) جنيه \\
\hline \multicolumn{6}{|c|}{ كبيرة (158-230) قيراط } \\
\hline \multicolumn{5}{|c|}{ 9ـ الوعي بمشكلات المجتمع المحلي: } & 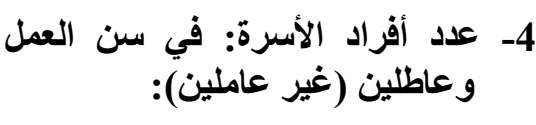 \\
\hline 22.44 & 55 & المنخفضة (3-4) درجة & 6.12 & 15 & لا يوجد \\
\hline 60 & 147 & المتوسطة (5-6) درجة & 21.63 & 53 & فرد واحد \\
\hline \multirow[t]{3}{*}{17.56} & 43 & المرتفعة (7-8) درجة & 22.44 & 55 & فرديــن \\
\hline & & & 49.81 & 122 & 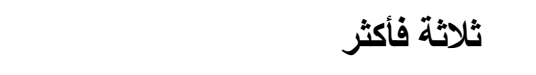 \\
\hline & \multicolumn{4}{|c|}{ 10ـ الرضا عن الخدمات بالقرية: } & 5- درجة الانتماء للمجتمع: \\
\hline 51.84 & 127 & منخفض (10-16) درجة & 20.41 & 50 & منخفضة (14-5) درجة \\
\hline 29.39 & 72 & متوسط (17-23) درجة & 15.69 & 40 & متوسطة (15-21) درجة \\
\hline 18.77 & 46 & مرتفع (24-30) درجة & 63.90 & 155 & مرتفعة (27-22) درجة \\
\hline
\end{tabular}

المصدر: جمعت وحسبت من التحليل الاحصائي لبيانات الدر اسة.

جدول 2. مستوى استفادة الأسر الريفية من أساليب الحماية الاجتماعية بمنطقة البحث لأن

\begin{tabular}{|c|c|c|}
\hline$(\%)$ & 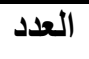 & الفئـــات \\
\hline 38.77 & 95 & المستوى المنخفض (27-27) درجة \\
\hline 41.64 & 102 & المستوى المتوسط (45-63) درجة \\
\hline 19.59 & 48 & المستوى المرتفع (64-81) درجة \\
\hline 100 & 245 & المجمــــوع \\
\hline
\end{tabular}


جدول 3. مفهوم الحماية الاجتماعية من وجهة نظر الريفيين ومُرتبة تنازلياً وفقاً لأهميتها النسبية

\begin{tabular}{|c|c|c|c|}
\hline$(\%)$ & العدد & مفهوم الحماية الاجتماعية & $\overrightarrow{5}$ \\
\hline 96.73 & 237 & معاش شهري لغير القادرين & $\overline{1}$ \\
\hline 91.02 & 223 & مساعدة الفقراء & 2 \\
\hline 89.79 & 220 & وصول الدعم للفقراء & 3 \\
\hline 87.75 & 215 & تأمين صحي لكل أفراد الأسرة & 4 \\
\hline 85.31 & 209 & الحق لكل أفراد المجتمع في التعليم المجاني & 5 \\
\hline 82.44 & 202 & توفير مستلزمات الإنتاج للزراع & 6 \\
\hline 81.22 & 199 & مساعدة المرضى وعلاجهم & 7 \\
\hline 77.14 & 189 & توفير الأدوية والعلاجات المجانية & 8 \\
\hline 70.20 & 172 & توفير السلع الأساسية ودعمها للفقراء & 9 \\
\hline 69.79 & 171 & وصول الدعم لمستحقيه & 10 \\
\hline 68.16 & 167 & مشاركة الفقراء و المهمشين في برامج التنمية & 11 \\
\hline 53.88 & 132 & توفير حياة كريمة للفقراء & 12 \\
\hline 53.88 & 132 & توفير معاش تكافل وكرامة لغير القادرين & 13 \\
\hline 53.47 & 131 & ضمان حد أدنى من الدخل لكل الأسرة & 14 \\
\hline 52.24 & 128 & علاج غير القادرين على نفقة الدولة & 15 \\
\hline 51.84 & 127 & الحماية ضد المخاطر والأمر اض و إصابات العمل & 16 \\
\hline
\end{tabular}

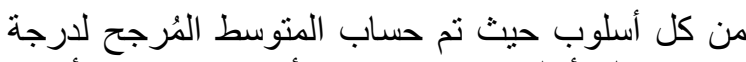

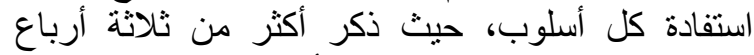

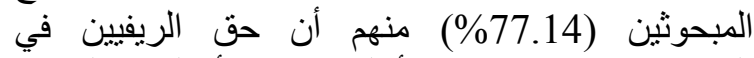
التصويت والانتخابات كأسلوب من أساليب الحئ الحماية

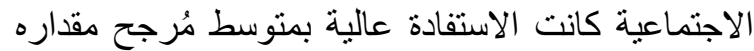
2.63 درجة و هو يمثل الترتيب الأول.

- و واحتل الترتيب الثاني من حيث الاستفادة أسلوب تشجيع

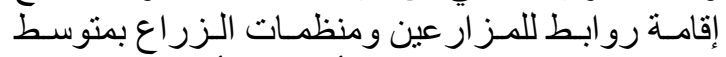

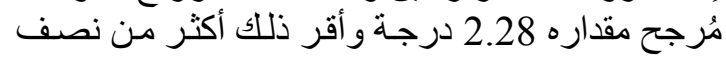
المبحوثين (55.10\%) كانت استفادتهم عالية.

- وجاء في النرتيب الثالث أسلوب دعم السلع الإستهلاكية

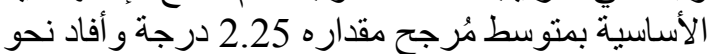

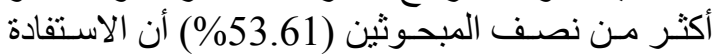
كانت عالية، في حين ذكر ما يقرب من ثلث الثن المبحوثين

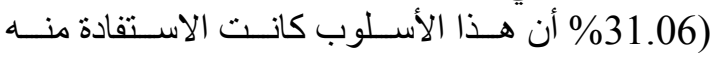

منخفضة.

- وجاء في الترتيب الر ابع أسلوب تعليم الريفيين وحقهم

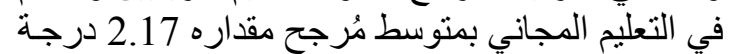
وأَثار أكثر من نصف المبحوثين (51.02\%) أن هذا الأسلوب كانت الاستفادة منه مرتفعـة، في حين أن أنُلث
أن الحماية الاجتماعية هي توفير معانش تكافل وكر امة أنة

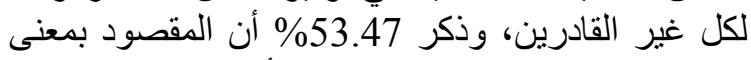

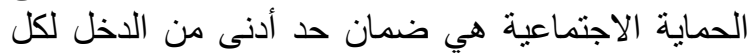

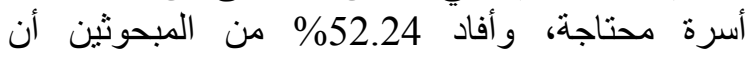

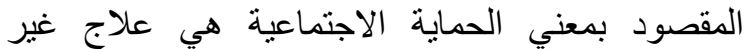

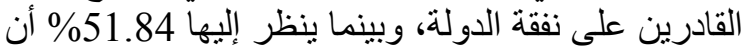

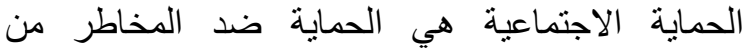

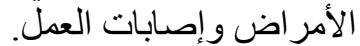

ونستنتج مما سبق أن المبحوثين يرون مفاهيم مختلفة

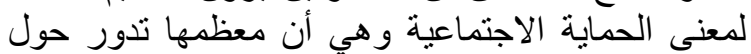

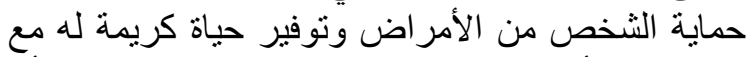

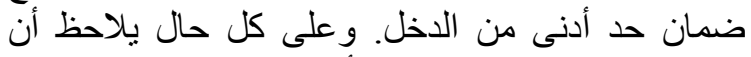
الريفيين المبحوثين يدركون أو يعرفون معنى الحماية يلانية

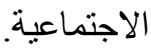

درجة الاستفادة من أساليب الحماية الاجتماعية للأسر الريفية كلاً على حدى بمحافظة الإسماعيلية من وجهة نظر المبحوثين

وللتعرف على درجة الاستفادة من أساليب الحماية

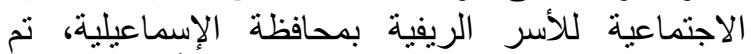

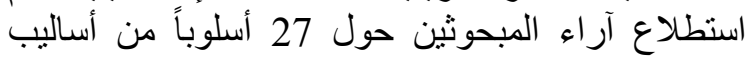
الحماية الاجتماعية، وذللك بسؤ الهح عن درجة الأل الستفادة 


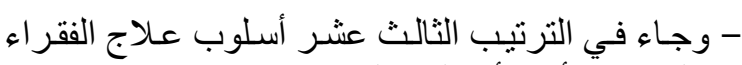

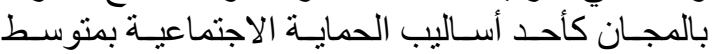

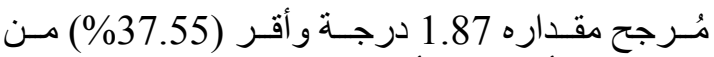

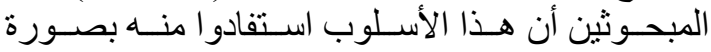

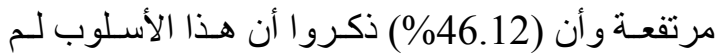

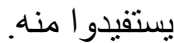

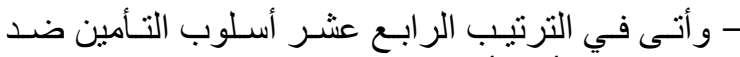

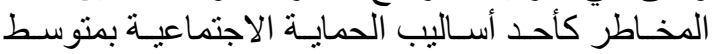

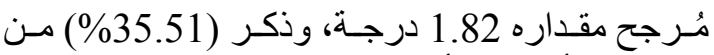

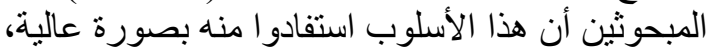

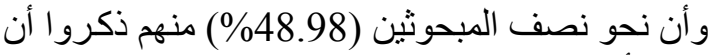
هذا الأسلوب لم بستفيدو ا منه.

-وجاء في الترتيب الخامس عشر أسلوب العدالة في توزيع الأر اضي الزراعية المستصلحة بمتوسط دُرجح

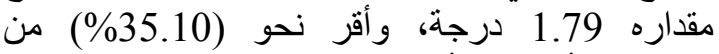

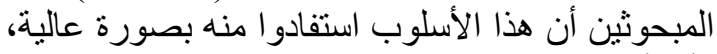

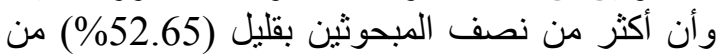
المبحوثين ذكروا أن هذا الأسلوب لم يستفيدوا منه.

-وجاء في الترنيب السادس عشر أسلوب مساعدة

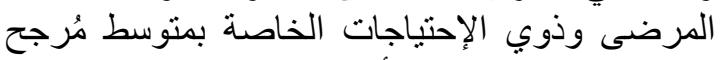

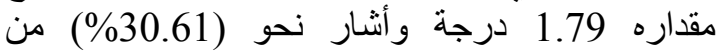
المبحوثين أن هذا الأسلوب كانت استفادتهم مرتفعة،

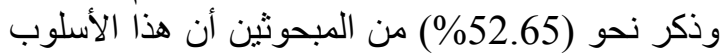

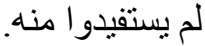

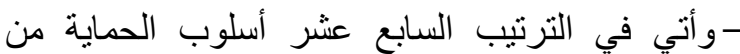
إصابات العمل و العجز بمنوسط مُرجح مقداره 1.76 درجة وأقر على أن هذا الأسلوب استفادوا منه (29.79\%) من المبحوثين وأن نحو (50.20\%) أثنار أنه لم بتم الاستفادة منه.

-وجاء في الترتيب الثامن عشر أسلوب وجود سياسة سعرية وراضحة للمحاصيل بمتوسط مُرجح مقداره

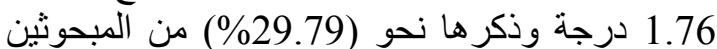

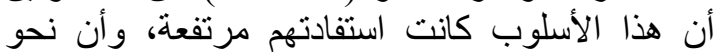
(53.88\%) منهم أشاروا أن هذا الأسلوب لم يستفيدوا

-وجاء في الترتيب التاسع عشر أسلوب التسويق

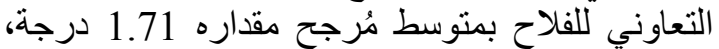

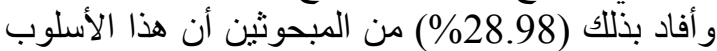

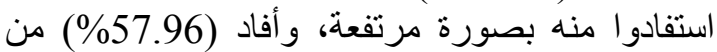

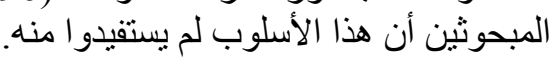

- وأتى في الترتيب العاثرون أسلوب تقديم الدعم المادي

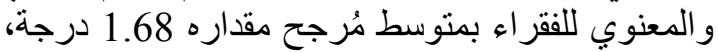
و أقر ذلك نحو (25.71\%) من المبحوثين أن هذا
المبحـوثين (33.47\%) ذكـروا أن هـذا الأسـلوب لـــ سيتفيدو ا منه.

- و أتـى فـي الترتيـب الخـامس دعـم مسـتلزمات الإنتـاج

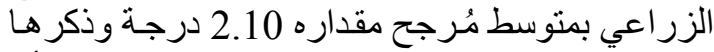

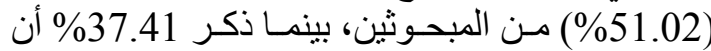
هذا الأسلوب لم يستفيدوا منه.

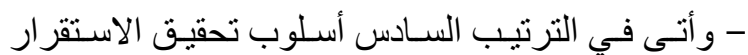

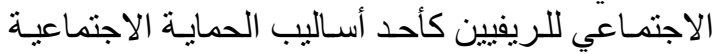

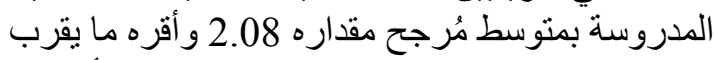

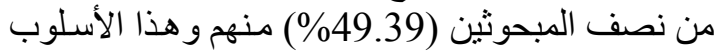

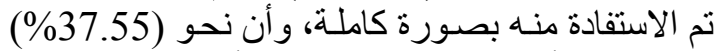

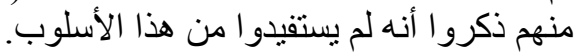

- وجـاء في الترتيـب السـابع وجـود نظـام عـادل لإيجـار

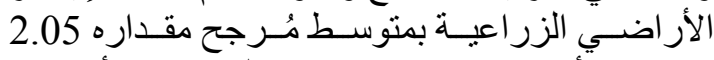

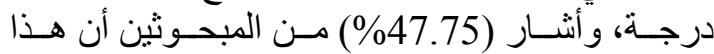

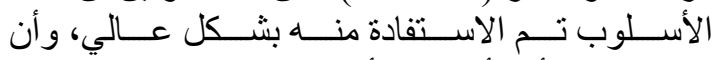
(237.55) أفاد أن هذا الأسلوب لم يستفيدو ا منه.

- وجـاء في الترتيب الثامن أسـلوب توفير سكن صـحي و أمنى بمتوسط مُرجح مقداره 2.004 درجة، و وأقر هذّا الأسلوب نحو (45.71\%) من المبحوثين على أنسه تـم

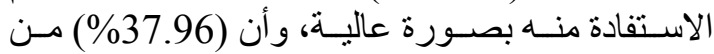

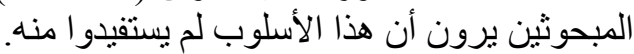

- وجاء في الترتيب التاسـع أسلوب المسـاعدة الاجتماعيـة

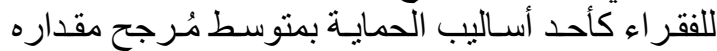

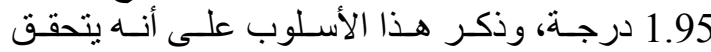
بدرجة كاملـة (44.49\%) مـن المبحوثين، و أشـار نحو النه

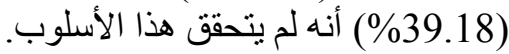

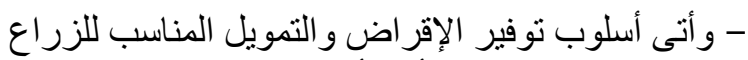
في الترتيب العاشـر كأحد أسـاليب الحمايـة الاجتماعيـة

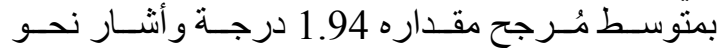
(43.26\%) مـن المبحـوثين أن هذا الأسـلوب اسـتفادوا

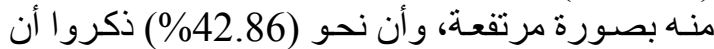
الأسلوب لم بستفيدو ا منه.

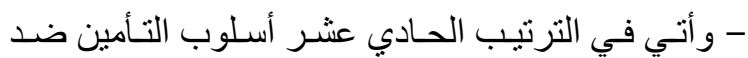

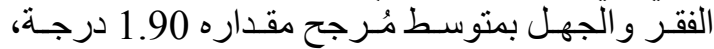
و أقر نحو (41.63\%) من المبحوثين أن هذا الأسلوب مئو

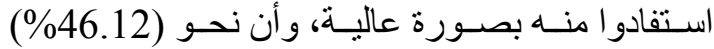
ذكرو ا أن هذا الأسلوب لم الم يستفيدو المنه.

- و أتى في الترنيب الثاني عشر أسلوب التـأمين الصـحي

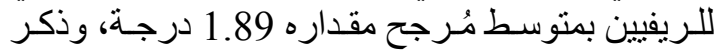

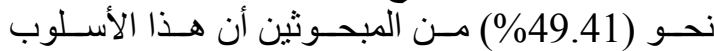

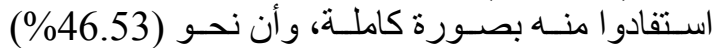
ذكرو ا أنه لم يستفيدو ا منهـ. 
يلاحظ من الجدول السابق أنه يوجد ثمانية أساليب

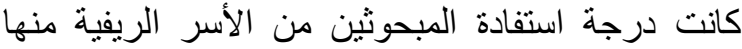

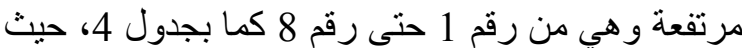

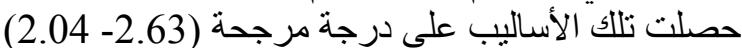
درجة من درجة قصوى 3، فحين باقي الأساليب نالت

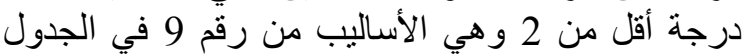
حتى رق27 وحصلت على درجة مرجحة ما بين (1.951.33) درجة من درجة قصوى على 3.

ربما يرجع ارتفاع استفادة المبحوثين من الأساليب

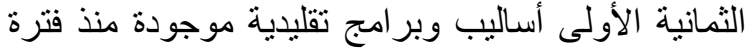

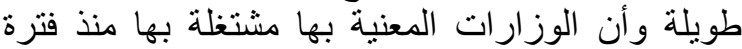

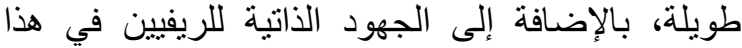

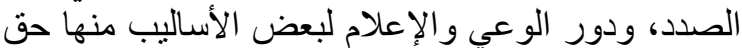

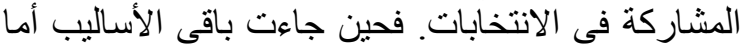

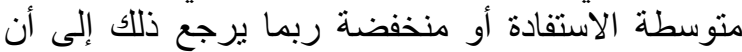
بعض الأساليب و البرامج مستحدثة إلى حد مألى مأل وأن الحكومة بدأت تأخذ بها بعض الخطوات مثل أسلوب

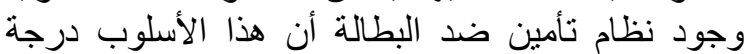

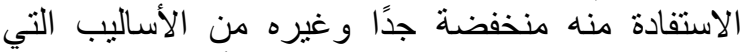

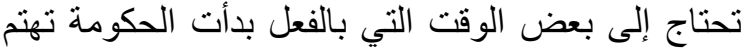

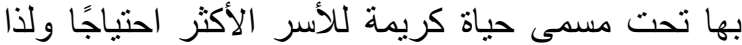

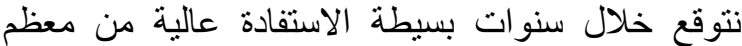
أساليب الحماية الاجتماعية للريفيين.

\section{العلاقات الارتباطية بين المتغيرات المُستقلة ودرجة استفادة المبحوثين من أساليب الحماية الاجتماعية التئة}

للتعرُف على العلاقة الارنباطية بين درجة استفادة المبحوثين من أساليب الحماية الاجتماعية والمتغيرات الاتهية المُستقلة المدروسة. تم وضع الفرض البحني في صورته الصفرية على النحو التالي: "لا توجد علاقة التهة ارتباطية

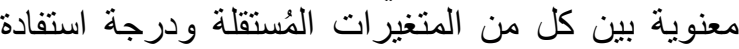

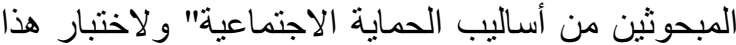
الفرض حسبت معاملات الارتباط البسيط، وتعكس النتائج الموضحة بجدول 5 النتائج الإحصائية.

ويتضح من بيانات الجدول ما يلي أنه يوجد ستة

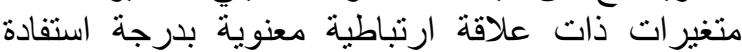
المبحوثين من أساليب الحماية الاجتماعية منهم خمسة إنة فئة متغير ات معنوية عند المستوى 0.01 وهي حجم الأسرة،

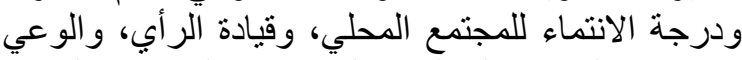

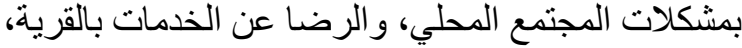
حيث بلغت قيم معاملات الارنباط البسيط بينهم مع المتغير الريا

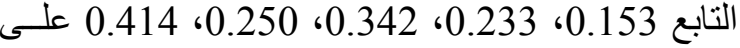
الترتيب، ويوجد متغير واحد فقط معنوي عند المستوى

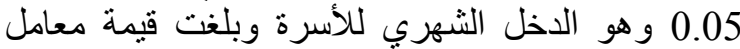
الارتباط البسيط لله -0.136 وهي قيمة معنوية عكسية. في حين لم توضح النتائج وجود علاقة إرتباطية معنوية

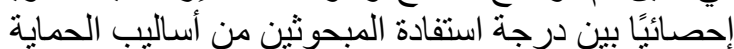

الأسلوب كانت استفادتهم مرتفعة، وأن نحو (57.14\%)

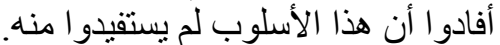

- وجاء في الترتيب الحادي والعشرون أسلوب نشجيع

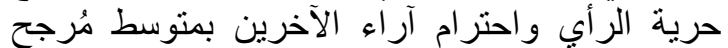

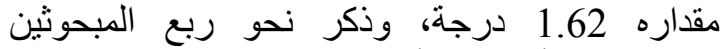
(25.71\%) أن هذا الأسلوب كانت استفادتهم مرتفعة، دود وأن نحو (59.18\%) من المبحوثين ذكروا أن هذا الأسلوب لم يستفيدو ا منه.

- و أتي في الترتيب الثاني والعشرون الاهتمام بالفلاح

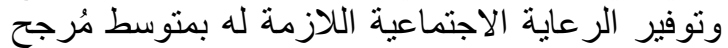
مقداره 1.59 درجة، و أفاد (21.63\%) من ألهابه المبحوثين اشاروا أن هذا الأسلوب كانت استفادتهم مرتفعة، وأن

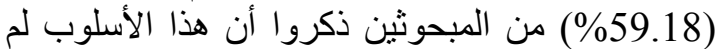
بستفيدوا منه.

- وجاء في الترتيب الثالث والعثرون إنشاء صندوق

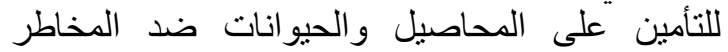
بمتوسط مُرجح مقداره 1.42 درجة، و أقر هذا الأسلوب المابـ

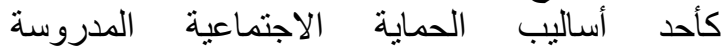

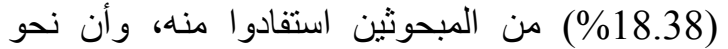
ثناثة أرباع المبحوثين (76.33\%) من المبحوثين أقر أن هذا الأسلوب لم يستفيدوا.

- أما أسلوب وجود نظام تأمين ضد البطالة جاء في الترنيب الر ابع و العشرون بمتوسط مُرجح مقداره 1.36

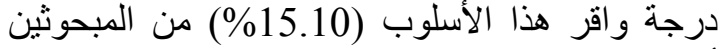
أنهم استفادوا بصورة درتفعة، وذكر نحو (18.77\%) منهم أن هذا الأسلوب لم يستفيدو ا منه.

- وجاء في الترتيب الخامس والعشرون أسلوب ضمان دخل مناسب للفقر اء بمتوسط مُرجح مقداره 1.33 درجة وأفاد نحو (14.28\%) من المبحوثين أن هذا الأسلوب استفادو ا منه بصورة مرتفعة، وذكر (81.82\%) وهم ثمانية أعشار المبحوثين أن هذا الأسلوب لهوبة لم يستفيدوا منه.

- وجاء في الترتيب السادس والعشرون أسلوب وجود نظام الزراعية التعاقدية للمحاصيل كأحد أساليب الحماية الاجتماعية بمتوسط مُرجح مقداره 1.24 درجة التها وذكرها حو الي خمس المبحوثين بنسبة (19.39\%) أن هذا الأسلوب استفادوا منها، وأن نحو (84.89\%) منهم ذكروا أن هذا الأسلوب لم يستفيدو ا.

- وجاء في الترتيب الأخير أسلوب مشاركة الريفيين في المشروعات التنموية بمتوسط مُرجح مقداره 1.22 درجة و أقرها نحو (8.57\%) من المبحوثين أن هذا مثنة

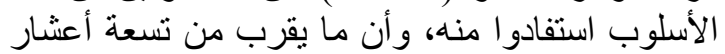

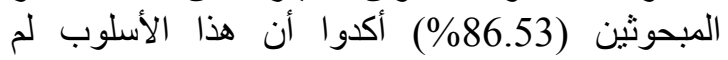
يستفيدوا منه. 
جدول 4. درجة استفادة المبحوثين من أساليب الحماية الاجتماعية كلاً على حدى

\begin{tabular}{|c|c|c|c|c|c|c|c|c|}
\hline \multirow{2}{*}{ المُرجح } & \multicolumn{2}{|c|}{ لم يستفيدوا } & \multicolumn{2}{|c|}{ استفادة متوسطة } & \multicolumn{2}{|c|}{ استفادة عالية } & \multirow[t]{2}{*}{ أساليب الحماية الاجتماعية } & \multirow[t]{2}{*}{ b } \\
\hline & $(\%)$ & 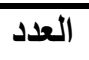 & $(\%)$ & 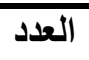 & $(\%)$ & 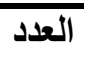 & & \\
\hline 2.63 & 10.20 & 25 & 12.65 & 31 & 77.14 & 189 & حق الريفيين في الانتخابات والتصويت & 1 \\
\hline 2.28 & 26.53 & 65 & 18.37 & 45 & 55.10 & 135 & تثجيع إقامة روابط للمزارعين ومنظمات الزراع & 2 \\
\hline 2.25 & 31.06 & 76 & 16.73 & 41 & 53.61 & 130 & دعم السلع الإستهلاكية الأساسية & 3 \\
\hline 2.17 & 33.47 & 82 & 15.51 & 38 & 51.02 & 125 & تعليم الريفيين وحقهم في التعليم المجاني & 4 \\
\hline 2.10 & 37.14 & 91 & 11.84 & 29 & 51.02 & 125 & دعم مستلزمات الإنتاج الزراعي & 5 \\
\hline 2.08 & 37.55 & 92 & 13.06 & 32 & 49.39 & 121 & تحقيق الاستقرار الاجتماعي للريفيين & 6 \\
\hline 2.05 & 37.55 & 92 & 14.69 & 36 & 47.75 & 117 & وجود نظام عادل لإيجاد الأراضي الزراعية & 7 \\
\hline 2.04 & 37.96 & 93 & 16.33 & 40 & 45.71 & 112 & توفير سكن صحي وأمني & 8 \\
\hline 1.95 & 39.18 & 96 & 16.33 & 40 & 44.49 & 109 & المساعدة الاجتماعية للفقراء & 9 \\
\hline 1.94 & 42.86 & 105 & 13.88 & 34 & 43.26 & 106 & توفير الإقراض والتمويل المناسب للزراع & 10 \\
\hline 1.90 & 46.12 & 113 & 12.24 & 30 & 41.63 & 102 & التأمين ضد الفقر والجهل & 11 \\
\hline 1.89 & 46.53 & 114 & 13.06 & 32 & 40.41 & 99 & التأمين الصحي للريفيين & 12 \\
\hline 1.87 & 46.12 & 113 & 16.33 & 40 & 37.55 & 92 & علاج الفقراء بالمجان & 13 \\
\hline 1.82 & 48.98 & 120 & 15.51 & 38 & 35.51 & 87 & التأمين ضد المخاطر & 14 \\
\hline 1.79 & 52.65 & 129 & 12.24 & 30 & 35.10 & 86 & العدالة في توزيع الأراضي الزراعية المستصلحة & 15 \\
\hline 1.82 & 50.75 & 127 & 16.14 & 41 & 30.61 & 77 & مساعدة المرضى وذوي الإحتياجات الخاصة & 16 \\
\hline 1.79 & 50.20 & 123 & 20.00 & 49 & 29.79 & 73 & الحماية من إصابات العمل والعجز & 17 \\
\hline 1.76 & 53.88 & 132 & 16.33 & 40 & 29.79 & 73 & وجود سياسة سعرية واضحة للمحاصيل & 18 \\
\hline 1.71 & 57.96 & 142 & 13.06 & 32 & 28.98 & 71 & التسويق التعاوني الفلاح & 19 \\
\hline 1.68 & 57.14 & 140 & 17.14 & 42 & 25.71 & 63 & تقديم الدعم المادي والمعنوي للفقراء & 20 \\
\hline 1.62 & 59.18 & 145 & 15.10 & 37 & 25.71 & 63 & تشجيع حرة الرأي واحترام آراء الآخرين & 21 \\
\hline 1.59 & 59.18 & 145 & 19.18 & 47 & 21.63 & 53 & الاهتمام بالقلاح وتوفير الرعاية الاجتماعية & 22 \\
\hline 1.42 & 76.33 & 183 & 5.31 & 13 & 18.37 & 45 & إنشاء صندوق للتأمين على المحاصيل و الحيوانات ضد & 23 \\
\hline 1.36 & 78.77 & 193 & 6.12 & 15 & 15.10 & 37 & وجود نظام تأمين ضد البطالة & 24 \\
\hline 1.33 & 81.8 & 198 & 4.90 & 12 & 14.28 & 35 & ضمان دخل مناسب للفقراء & 25 \\
\hline 1.24 & 84.89 & 208 & 5.71 & 14 & 9.39 & 23 & وجود نظام الزراعة التعاقدية للمحاصيل & 26 \\
\hline 1.22 & 56.53 & 212 & 5.31 & 13 & 8.57 & 21 & مشاركة الريفيين في المشروعات التنموية & 27 \\
\hline
\end{tabular}


جلول 5. نتائج تحليل الإرتباط البسيط والانحار الخطي المتعدد للمتثيرات المُستقلة ودرجة استفادة المبحوثين من أساليب الحماية الاجتماعية بمنطقة البحث.

\begin{tabular}{|c|c|c|c|c|}
\hline قيمة (ت) & قالجزئي معامل المعياريدار & الإرتباط البسيط معامل & المتغيرات المُستقلة & 5 \\
\hline 0.649 & 0.038 & 0.008 & الســـــن & 1 \\
\hline *2.307 & 0.137 & ** 0.153 & 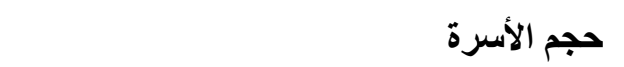 & 2 \\
\hline$* * 4.235-$ & $0.258-$ & *1.36- & الاخل الثهري & 3 \\
\hline *0.510 & 0.226 & 0.108 & عدد أفراد الأسرة غير العاملين في سن العمل & 4 \\
\hline 1.162 & 0.073 & ${ }^{* *} 0.223$ & درجة الانتماء للمجتمع المحلي & 5 \\
\hline${ }^{* *} 2.610$ & 0.149 & ${ }^{* *} 0.342$ & 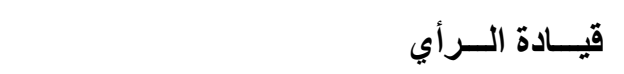 & 6 \\
\hline 1.41 & 0.26 & 0.076 & حجم الحيازة الحيوانية & 7 \\
\hline 0.899 & 0.052 & 0.092 & حجم الحيازة الزراعية & 8 \\
\hline 3.237 & 0.190 & ${ }^{* *} 0.250$ & الوعي بمشكلات المجتمع المحلي & 9 \\
\hline ** 5.473 & 0.323 & ${ }^{* *} 0.414$ & الرضا عن الخدمات بالقرية & 10 \\
\hline
\end{tabular}

المصدر: جمعت وحسبت من التحليل الاحصائي لبيانات الدراسة.

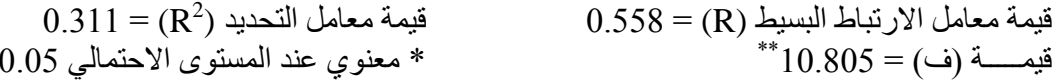

الأشخاص المدركين لمشاكل مجتمعاتهم هم الأشخاص

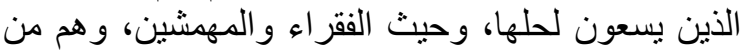

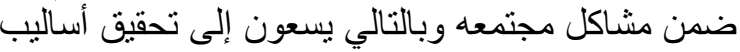

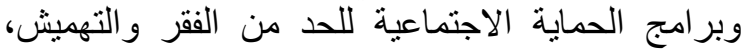

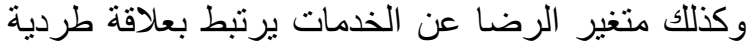

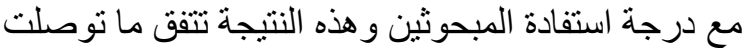

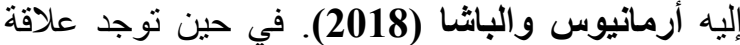

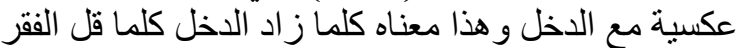

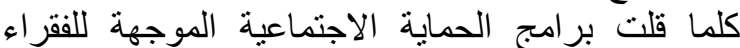
و المهمشين وتتفق مع توصل إليه كل من فانوس وآخرون الآن

.(2018)

ولا توجد علاقة مع حجم الحبازة الزراعية والحيو انية

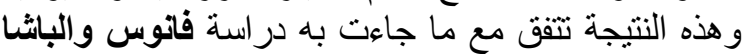

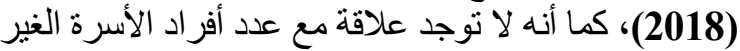

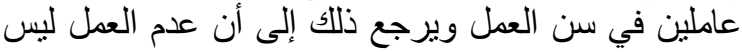
شرط لكي يكون الثخص ضمن فئ بر امج الحماية الاجتماعية،

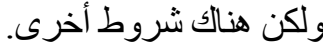

العلاقات الاتحدارية بين المتغيرات المُستقلة ودرجة فئة استفادة المبحوثين من أساليب الحماية الاجتماعية

للتعرف على محددات الاستفادة من أساليب الحماية

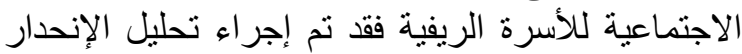

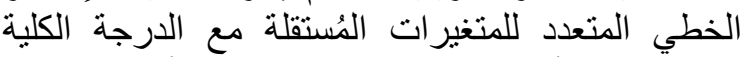
للاستفادة من أساليب الحماية الاجنماعية للأسرة الريفية. وفي ضوء ذللك تم وضع فرض البحث في صورته
الاجتماعية وبين كلاً من المتغيرات المُستقلة التالية عدد

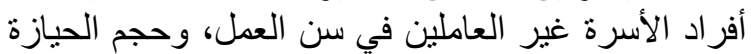

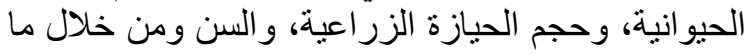

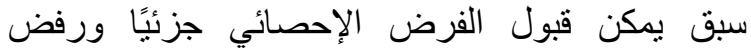
الفرض البديل جزئيًا.

تفسير نتائج العلاقات الارتباطية بين المتغيرات المستقلة ودرجة استفادة المبحوثين من أساليب تحقيق الحماية الاجتماعية

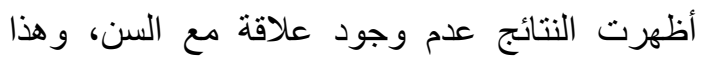
راجع إلى أن عامل السن في فترة ينطلب حماية النية

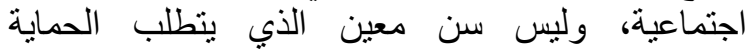

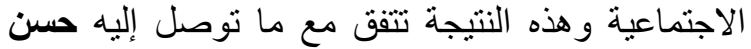
(2018)، كما يوجد علاقة بين متغير ملته تونم الأسرة

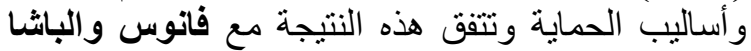
(2018)، يمكن تعليل أنه كلما زاد حجم الأسرة كلما كانت درجة الاستفادة من أساليب الحماية الاجنماعية، كما لإنا

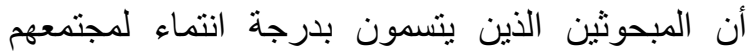

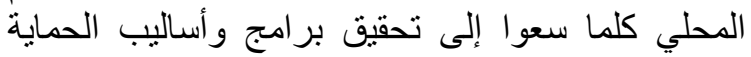
الاجتماعية عن طريق المشاركة التطو عية و غير ها و هذه

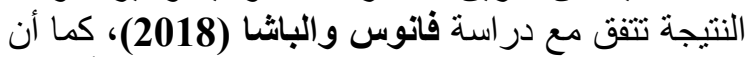

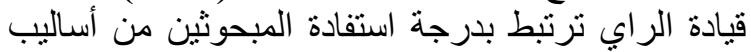

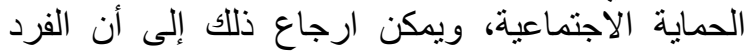

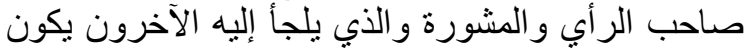
أكثر وعيًا بطرق وبرامج الحماية الاجتماعية، كما أن النية 
معادلة انحدار خطي تتضمن سبعة متغير ات مستقلة حيث

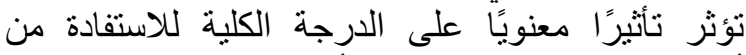

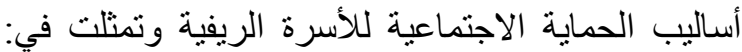

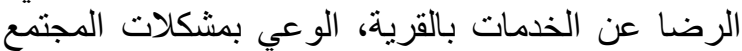

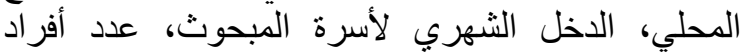

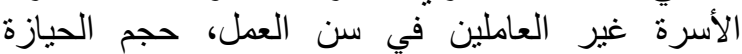
الحيو انية، درجة الانتماء للمجتمع المحلي، وقين العيادة الر أي.

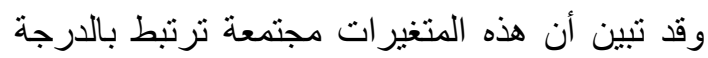

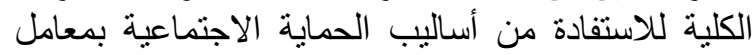

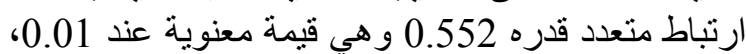

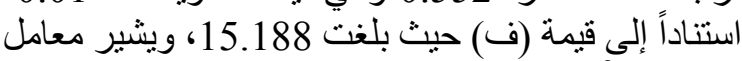

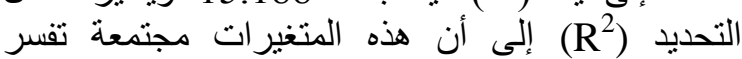
\% 30.5 فقط من التباين في المتغير التنابع كما بجدول 6.

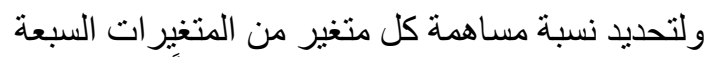

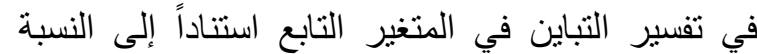

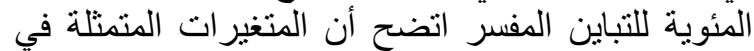

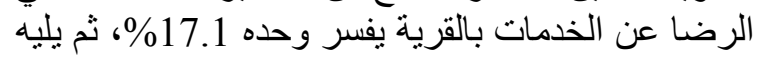

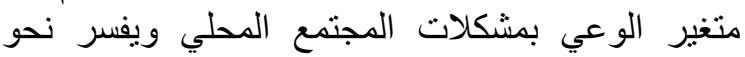

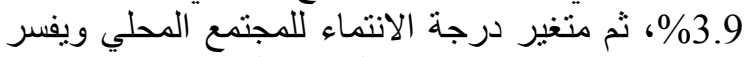

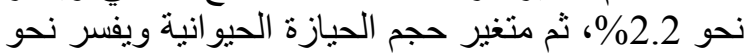

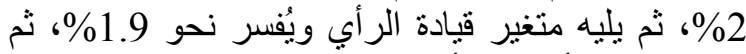
متغير عدد أفراد الأسرة غير العير العاملين ويفسر نحو

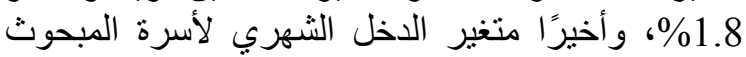

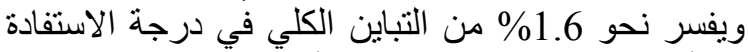

من أساليب الحماية الاجنماعية للأسرة الريفية.
الصفرية "لا ترتبط المتغيرات المُستقلة مجتمعة بالدرجة الكلية للاستفادة من أساليب الحماية الاجتماعية للأسرة

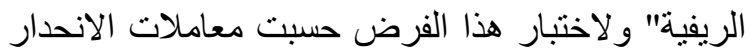

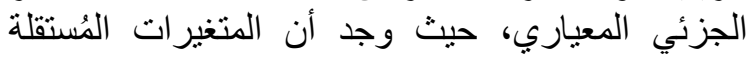

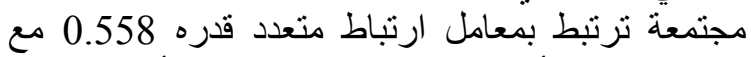
الدرجة الكلية لأساليب الحماية الاجتماعية للأسرة الريفية

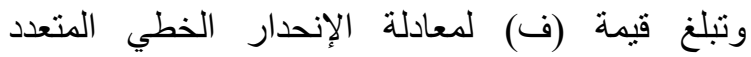

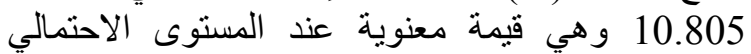

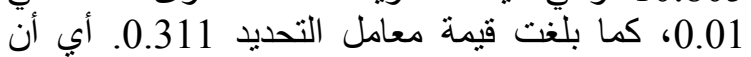

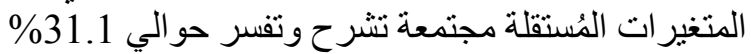
من التباين الكلي في الدرجة الكلية للاستفادة من أساليب

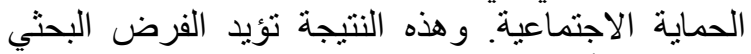

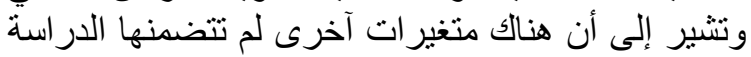

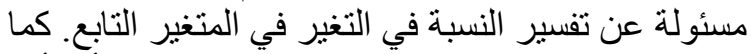

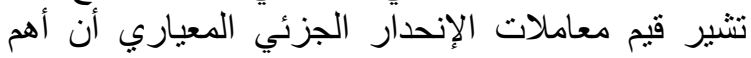

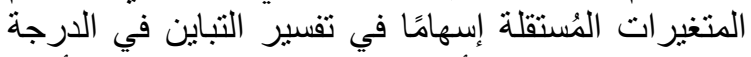

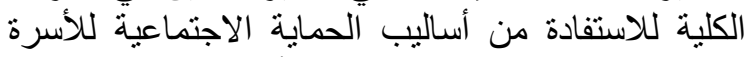

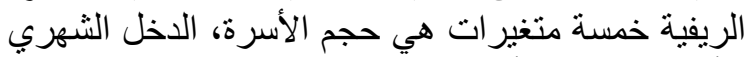

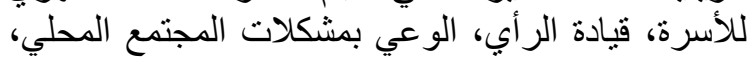

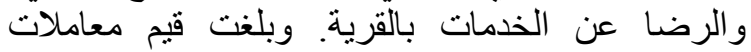
الإنحدار الجزئي المعياري لهذه المتغيرات

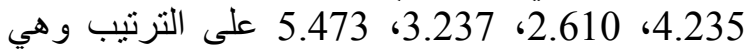

جميعها قيم معنوية عند المستوى الاحتمالي 0.01 .01$.

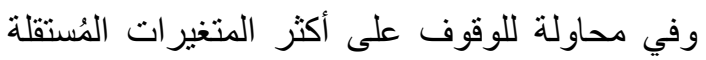

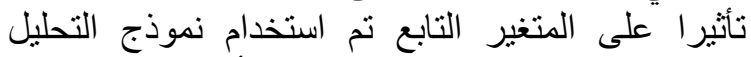
الإنحدار المتعدد التندرجي الصاعد فأسفر التحليل عن عن التيل

جدول 6. النموذج المخُتزل للأهمية النسبية للمتغيرات المُستقلة الأكثر إسهاماً في تفسير التباين للارجة الكلية للاستفادة من أساليب الحماية الاجتماعية لئية

\begin{tabular}{|c|c|c|c|c|c|}
\hline \% في اللتباين التففر & للتباين المفسر الترية & ق قيمةت ت & معائية المعياري الإدي & المتغيرات المُستقلة & p \\
\hline 17.1 & 0.171 & *5.830 & 0.325 & الرضا عن الخدمات بالقرية & 1 \\
\hline 3.9 & 0.210 & **5.87 & 0.198 & الوعي بمشكلات المجتمع المحلي & 2 \\
\hline 2.2 & 0.232 & **2.777 & 0.156 & درجة الإنتماء للمجتمع المحلي & 3 \\
\hline 2 & 0.252 & **3.700 & 0.233 & حجم الحيازة الحيوانية & 4 \\
\hline 1.9 & 0.271 & ${ }^{* *} 2.584$ & 0.145 & ق قيــادة الـــرأي & 5 \\
\hline 1.8 & 0.289 & **3.613 & 0.230 & عدد أفراد الأسرة غير العاملين في سن العمل & 6 \\
\hline 1.6 & 0.305 & ${ }^{* *} 4.226-$ & $0.250-$ & الاخل الشهري لأسرة المبحوث & 7 \\
\hline & & & & \multicolumn{2}{|l|}{ المصدر: جمعت وحسبت من التحليل الاحصائي لبيانات الدراسة } \\
\hline & \multirow{3}{*}{\multicolumn{2}{|c|}{ 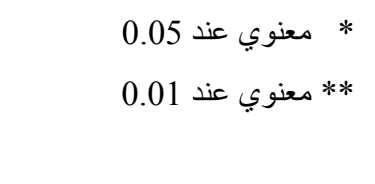 }} & & \multicolumn{2}{|c|}{ قيمة معامل الإرنباط المتعدد (R) } \\
\hline & & & & ة معامل التحديد (R2) & قيمة معامل التحديد (R2) \\
\hline & & & & \multicolumn{2}{|c|}{ قيمــــة (ف) } \\
\hline
\end{tabular}




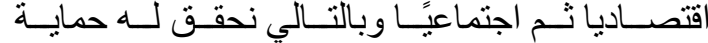

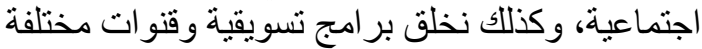

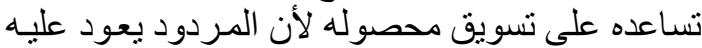

$$
\text { و وعلى المجتمع بأسره. }
$$

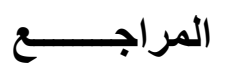

الأمم المتحدة (2013). تقرير الأهداف الإنمائية للألفية

2013، منشور صادر عن الامم المتحدة، رقم المبيع

E13109 نيويورك.

الأونكاد (2013). تقرير التجارة و التنمية لعام 2013، الأنيان

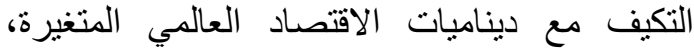
منشور صنادر عن الأمم المتحدة، رقم المبيع

.E.T.II.D3

الجهاز المركزي للتعبئة العامة والإحصاء (2015). الاخل و الانفاق و الاستهلاك.

الجهاز المركزي للتعبئة العامة والإحصاء (2017). مصر.

الجهاز المركزي للتعبئة العامة والإحصاء ويونيسف الإنف

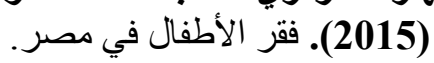

الحماية الاجتماعية فقر الأطفال، ناريخ 17 أكتوبر . 2019

العبيدي، محمد جاسم (2009). مدخل الي علم النفس العام، دار الثقافة للنشر و التوزيع.

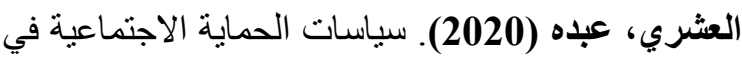

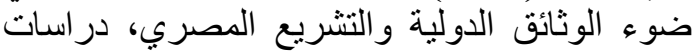
في حقوق الإنسان.

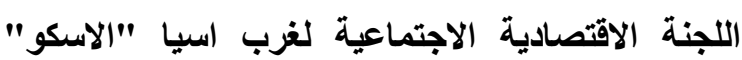

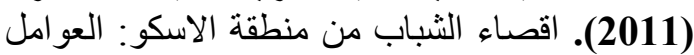

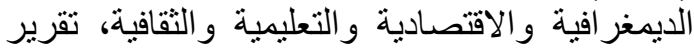

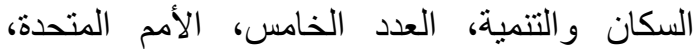

$$
\text { نيويورك. }
$$

الهنيدى، رضوان أحمد، سلامة، فؤاد عبد اللطيف لونيف

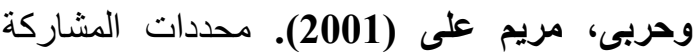
السياسية للمر أة الريفية بإحدى قرى محافظة البحيرة،

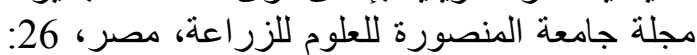

برنامج الأمم المتحدة الإنمائي (2010). الفقر اءو الموششين. جهاز تطوير العثوائيات ويونيسف (2003). فقر الأطفال

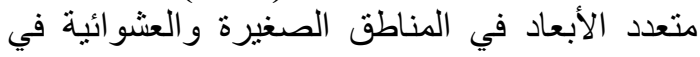

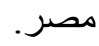

حسن، محمود حسن (2017): آليات الحماية الاجنماعية

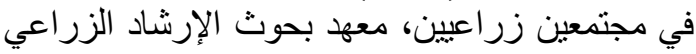

التوصيـــــــات

بناءاً على نتائج الدر اسة يمكن التوصية بما يلي:

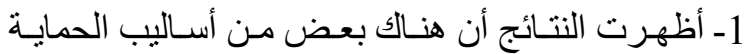

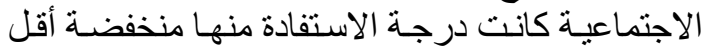

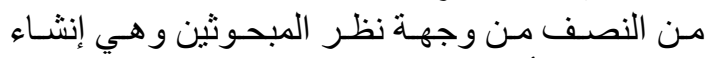

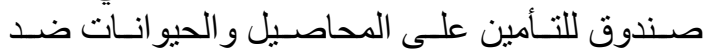

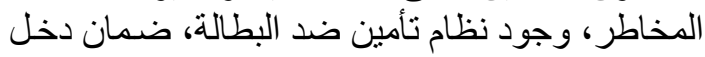

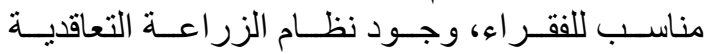

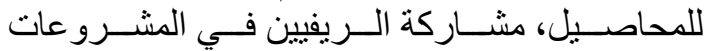

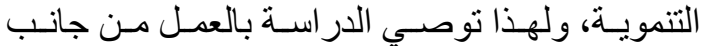

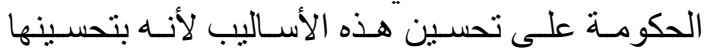

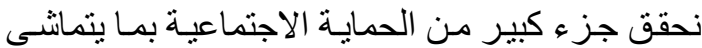
مع اتفاقية العمل الدولية.

2- يجب العمل على توعية الريفيين وتثقيفهر على كيفية

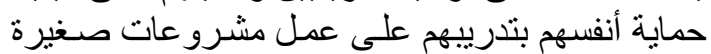

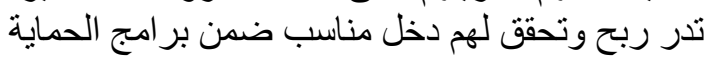

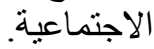

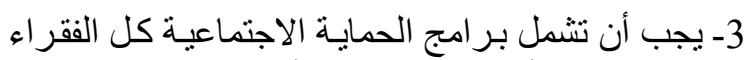

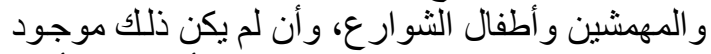

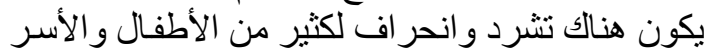

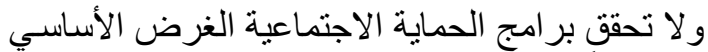

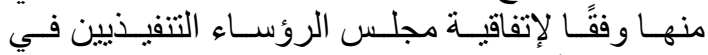

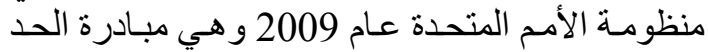
الأدنى من الحماية الاجتماعية.

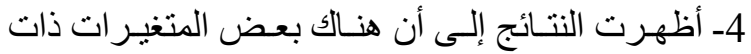

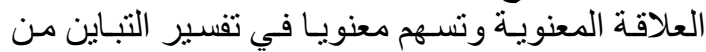

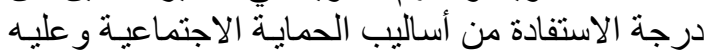

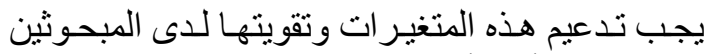

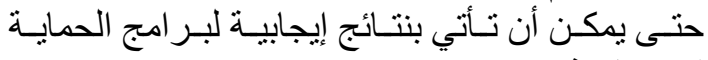

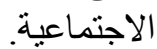

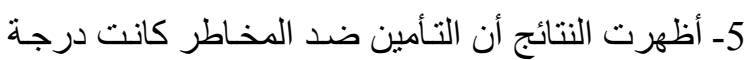

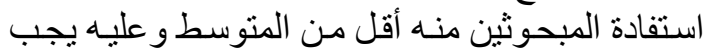

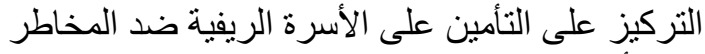
حيث أن كثير من العمليات الزر اعية يو جد بها مخاطر لألئ صحية وجسمية.

6- كثفت النتائج إلى أن درجة استفادة الفقر اء مـن العلاج

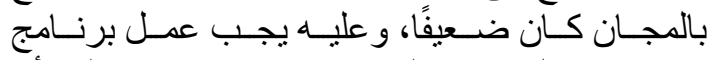

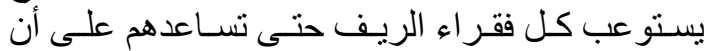
يحيو ا حياة كريمة.

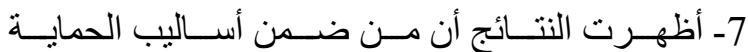

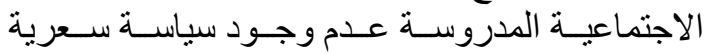

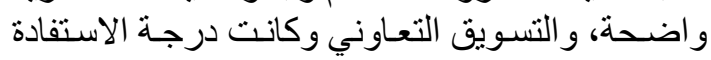

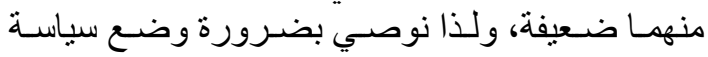

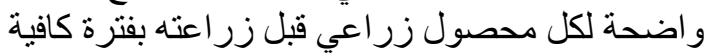

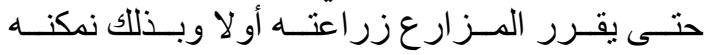


منظمة العمل العربية (2001). الحماية الاجتماعية حق الدقاية لكل مواطن، مؤتمر العمل المصري، العملي، الدورة 28، عمان، 2-19 إبريل.

هاشم، صلاح (2014). الحماية الاجتماعية للفقراء،

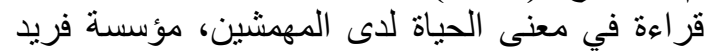

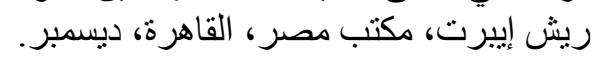

هاشم، يحي محمد محمد (2015): آليات الحماية الاجتماعية في مصر: دراسة تحليلية مجلة البحث البثة العلمي في الآداب، جامعة عين شمس، كلية البنات، $1: 16$

هاشم، يحيى محمد محمد (2016): آليات الحد من الفقر في الريف المصري: در اسة ميدانية لنبكات الحماية

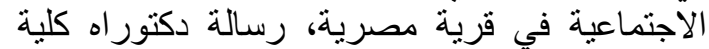
البنات للادداب و العلوم و التربية، قسم علم الاجتماع،

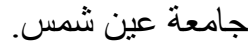

وزارة المالية (2017). موازنة المواطن، حقك تعرف الزف مو ازنة بلدك، كتيب مبسط، الإصدار الر ابع، سبتمبر.

وهبة، أحمد جمال الدين، ويسري عبدالمولي رميح وسونيا محي الاين نصرت (2017). الحماية الآجتماعية

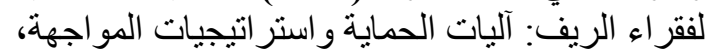

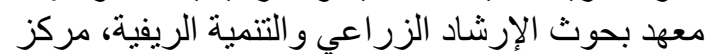

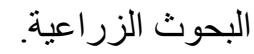

Avner, M. (2009). Lobbying and Advocacy Handbook for Nonprofit Organizations, Shaping Public Policy at the State and Local Level (Publisher, Fields one All once, New York.

Bhalla, A.S. and Lapery (2004). Poverty and Exclusion in a global word $\left(2^{\text {nd }}\right.$ Rev. Ed) Hampshire: Macmillan.

International day for the Eradication of poverty

Norton, A.T.M. (2001). Social Concepts and Approaches, Implications for Practice in International Development, Working Paper 143M Center for aid public Expenditure, Overseas Development Institute, London, UK.
و التنمية الريفية، نشرة بحثية، مجلة الاقتصاد الزر اعي و العلوم الاجتماعية، 7: 5.

سليمان، نادية حليم (2008). الأطفال الذين يقيمون في

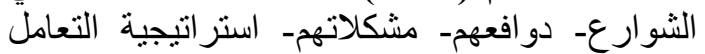
معهم، المؤتمر السنوي الثنامن و الثناثنون لقضايا السكان و التتمية (الو اقع و التحديات)، 16-18 ديسمبر.

شوشان، سامية جابر (2008). الإستر اتيجية البيئية بين

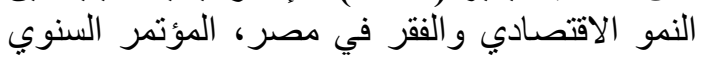

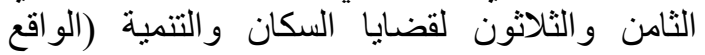
و التحديات)، 11-18 ديسمبر.

عبد السيد، فرحات (2011). محددات المشاركة السياسية

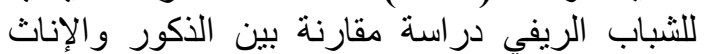

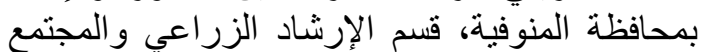
الريفي، كلية الزراعة، جامعة المنوفية، مجلة الزية اتحاد

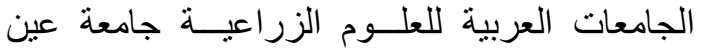
شمس، القاهرة، 19: 19.

عبدالباقي، عزة عبدالظاهر (2012). تصور مقترح

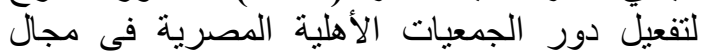

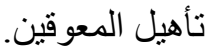

عوض، هالة شعبان (2014). برنامج مكافحة الفقر

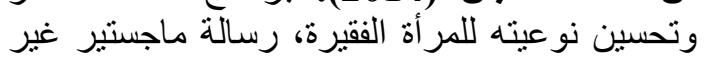
منشورة، كلية الخدمة الاجتماعية، جامعة حلو النئ

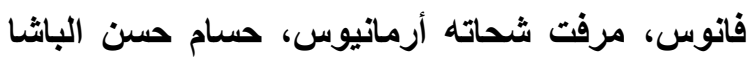
(2018). آراء الريفيين في أساليب الحماية الاجتماعية بقريتين بمحافظة المنوفية، المجلة المصرية الميلة اللعلوم التطبيقية، 33: 11. 11.

كوكبوم (2014). تعزيز العدالة للأطفال في سياق إصلاح دعم الطاقة في مصر.

مركز المعلومات ودعم واتخاذ القرار بمحافظة الإسماعيلية (2020).

مركز بصيرة لبحوث ودراسة الرأي العام (2014). الفقر

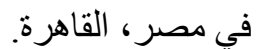

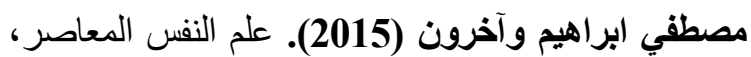
دار الامه للطباعة و النشر و التوزيع، الجز النمائر. منظمة الأغذية والزراعة للأمم المتحدة (2012). النمو

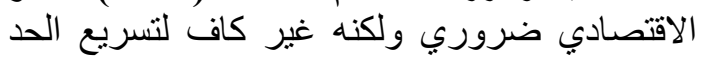
من الجوع وسوء التغذية، تقرير حالة التعدام الأمن الغذائي في العالم لعام 2012، روماء. 


\section{الملخص العربي \\ أساليب الحماية الاجتماعية للأسرة الريفية بمحافظة الإسماعيليـة}

\section{رائد عبدالناصر سلامةة1، مروان مصطفي حسن2}

1. قسم الاقتصاد و التتمية الريفية، كلية العلوم الزر اعية البيئية، جامعة العريش، مصر.

2. قسم إدارة مؤسسات الأسرة و الطفولة، كلية الاقتصاد المنزلي، جامعة العريش، مصر.

استهدف البحث التعرف على أساليب الحماية الاجتماعية ودرجة الاستفادة منها من وجهة نظر المبحوثين. وقد

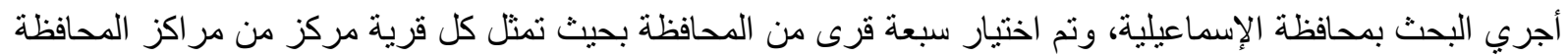

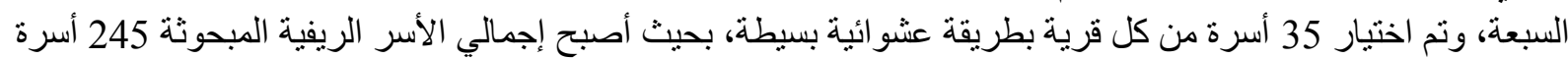

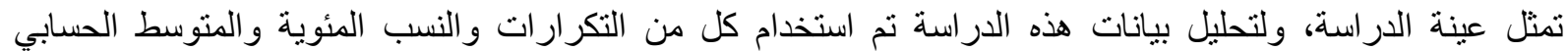

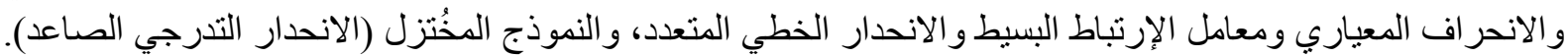
وقد توصل البحث إلى العديد من النتائج كان من أهمها ما يلي: أظهرت النتائج أن معظم المبحوثين يدركون معنى مفهوم الحماية الاجتماعية، كما أوضحت الدراسة أنه يوجد 27 أسلوب من أساليب الحماية الاجتماعية وكان منوسط درجة العانية

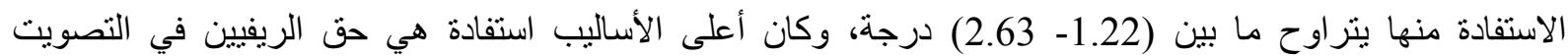
و الانتخابات بدرجة منوسطة قدر ها 2.63 درجة، وكان أقلها هو أسلوب مشاركة الريفيين في المشروعات التان التنموية بدرجة

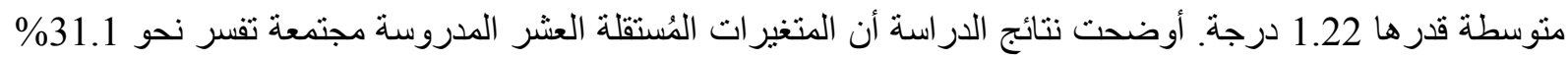
من التباين الكلي في الدرجة الكلية لاستفادة المبحوثين من اساليب الحماية الاجتماعية. الكلمات الاسترشادية: أساليب الحماية الاجتماعية، الحماية الاجتماعية، برامج الحماية الاجتماعية.

أستاذ الاجتماع الريفي، كلية الزر اعة، جامعة الفيوم، مصر. أستاذ إدارة المنزل و المؤسسات، كلية الاقتصاد المنزلية الزئ جامعة المنوفية، مصر. 